Review

\title{
Artificial Intelligence and Machine Learning in Chronic Airway Diseases: Focus on Asthma and Chronic Obstructive Pulmonary Disease
}

\author{
Yinhe Feng ${ }^{1,2^{*}}$, Yubin Wang ${ }^{1 *}$, Chunfang Zeng2 ${ }^{2}$, Hui Mao ${ }^{1}$ \\ 1. Department of Respiratory and Critical Care Medicine, West China Hospital, Sichuan University, Chengdu, Sichuan Province, China. \\ 2. Department of Respiratory and Critical Care Medicine, People's Hospital of Deyang City, Affiliated Hospital of Chengdu College of Medicine, Deyang, \\ Sichuan Province, China. \\ *These authors contributed equally to this work. \\ $\triangle$ Corresponding author: Hui Mao, Department of Respiratory and Critical Care Medicine, West China Hospital, Sichuan University, \#37 Guoxue Alley, \\ Chengdu 610041, China. Tel: (+86) 028-85423061, Fax: (+86) 028-2220098. E-mail: merrymh@126.com. \\ (0) The author(s). This is an open access article distributed under the terms of the Creative Commons Attribution License (https://creativecommons.org/licenses/by/4.0/). \\ See http://ivyspring.com/terms for full terms and conditions.
}

Received: 2021.01.14; Accepted: 2021.05.20; Published: 2021.06.01

\begin{abstract}
Chronic airway diseases are characterized by airway inflammation, obstruction, and remodeling and show high prevalence, especially in developing countries. Among them, asthma and chronic obstructive pulmonary disease (COPD) show the highest morbidity and socioeconomic burden worldwide. Although there are extensive guidelines for the prevention, early diagnosis, and rational treatment of these lifelong diseases, their value in precision medicine is very limited. Artificial intelligence (Al) and machine learning $(\mathrm{ML})$ techniques have emerged as effective methods for mining and integrating large-scale, heterogeneous medical data for clinical practice, and several $\mathrm{Al}$ and $\mathrm{ML}$ methods have recently been applied to asthma and COPD. However, very few methods have significantly contributed to clinical practice. Here, we review four aspects of $\mathrm{Al}$ and $\mathrm{ML}$ implementation in asthma and COPD to summarize existing knowledge and indicate future steps required for the safe and effective application of $\mathrm{Al}$ and $\mathrm{ML}$ tools by clinicians.
\end{abstract}

Key words: artificial intelligence; machine learning; chronic airway diseases; asthma; chronic obstructive pulmonary disease

\section{Introduction}

Recent developments in computer operations and the rapid development of "big data" have significantly advanced artificial intelligence (AI) and machine learning (ML) technology and their applications in various fields such as medicine [1]. Medical data are difficult to capture, manage, and process using conventional tools in a timely manner because the datasets are huge, they are frequently updated, and the data come in diverse formats. Instead, imaging, genomic, proteomic and electronic health records (EHRs) data can be mined using AI/ ML to extract new knowledge [2]. This development has led to rapid changes in the use of $\mathrm{AI} / \mathrm{ML}$ in medicine, especially in medical imaging [3], where the techniques are used not only for rapid disease screening, but also to improve diagnostic accuracy and work efficiency [4]. Genomic data are another enormous source of complex medical information that has recently emerged. Recent studies have demonstrated that the systematic analysis of genomic data with $\mathrm{AI} / \mathrm{ML}$ technology can favor precision medicine for the benefit of patients [5, 6]. Although the most widely used AI/ML technology in respiratory diseases is chest imaging, especially for the screening and diagnosis of lung nodules, the application of $\mathrm{AI} / \mathrm{ML}$ tools in chronic airway diseases is attracting increasing attention $[7,8]$.

Chronic airway diseases, such as asthma, chronic obstructive pulmonary disease (COPD) and bronchiectasis, are lifelong and life-threatening pathological conditions that extensively affect people of all ages, races, and sex worldwide [9]. These 
diseases are characterized by airway inflammation, obstruction, and remodeling, and common symptoms include cough, sputum, and shortness of breath. Their etiology and pathogenesis are complex and not yet fully understood $[10,11]$. Patients with chronic airway diseases are also prone to relapse, increasing their risk of hospitalization and death, and seriously affecting their quality of life. Among these diseases, asthma and COPD lead to the highest morbidity and socioeconomic burden worldwide [12]. Despite extensive efforts, identifying, treating and managing both disorders still face many challenges, such as under- and overdiagnosis, unclear pathogenesis, lack of uniform classification criteria for phenotypes, and high risk of death and high costs associated with exacerbations [13]. In addition, several $\mathrm{AI} / \mathrm{ML}$ methods have recently been applied for both diseases, but only a few have significantly contributed to clinical practice. Thus, summarizing existing knowledge and indicating future directions is required for the safe and effective application of AI/ML tools by clinicians. Here, we systematically review the application of $\mathrm{AI} / \mathrm{ML}$ technology to four different aspects of asthma and COPD: screening and diagnosis, classification and assessment, management and monitoring, as well as treatment (Figure 1). We also present the development of several models based on ML algorithms.

\section{General concepts, terminologies and limitations of $\mathrm{AI} / \mathrm{ML}$}

In order to facilitate understanding, we quickly explain the general concepts and terminologies of $\mathrm{AI} / \mathrm{ML}$ that commonly appeared in this review. In addition, we summarize the evaluation indicators and current limitations of ML.

In general, AI refers to the technology that represents human intelligence through computer programs. ML is a branch of AI technology based on statistical techniques for self-learning and the development of problem-solving skills. In particular, ML uses complex algorithms to analyze large amounts of data, identify patterns, make predictions that do not require specific codes, and evolve with increasing sample size to improve learning. ML technology can be divided into supervised, semi-supervised, unsupervised and reinforcement learning [14, 15] (Figure 2). Supervised learning trains ML algorithms to labeled data. These labels, that include data types, data attributes and feature point locations, are used as expected effects to continuously modify the prediction results of the ML model.

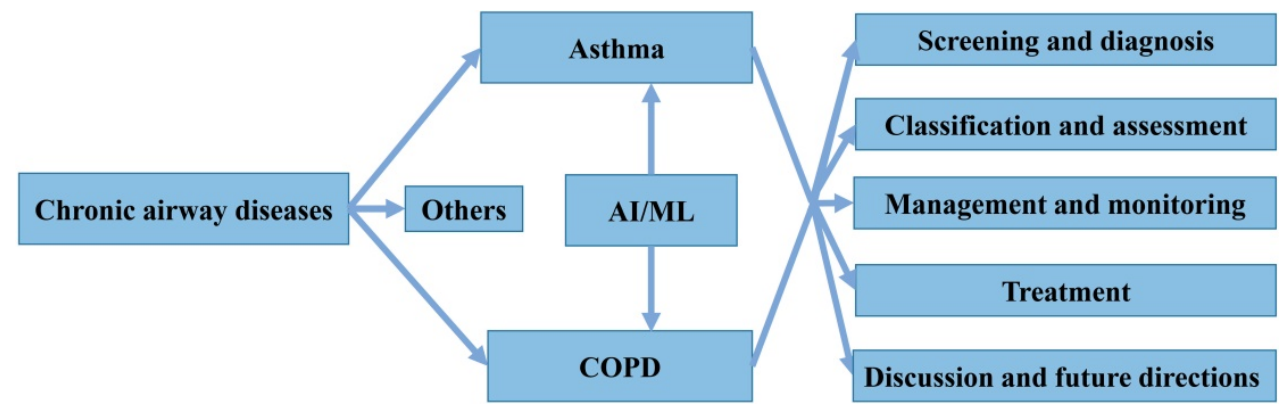

Figure 1. Structure of the present review.

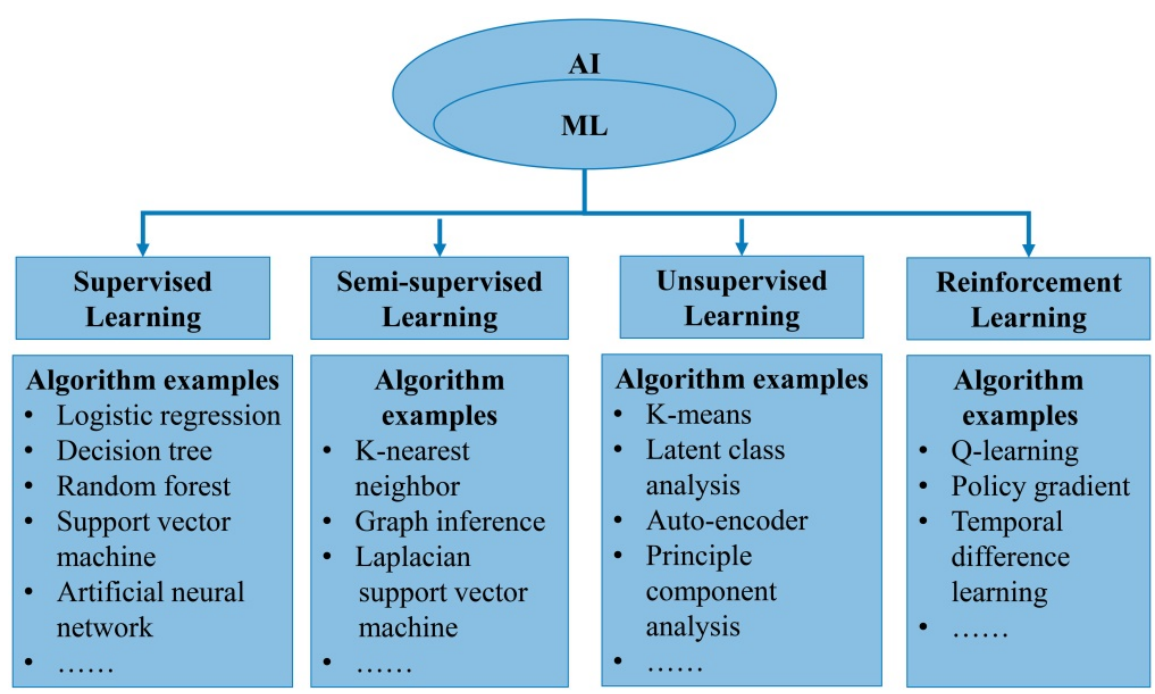

Figure 2. Categories of machine learning algorithms. 
Common tasks for supervised learning are regression and classification for continuous and categorical outcome variables, respectively [15]. Semi-supervised learning can fit models to not only labeled data but also unlabeled data. When this type of ML algorithm classifies unlabeled data, it usually measures the distance/similarity between the target sample and all labeled samples [16]. Unsupervised learning aims to explore and infer potential natural connections and groupings from unlabeled data [17]. Reinforcement learning, in contrast, is a general term for ML approaches that integrate prediction and decision-making. This type of ML technology has an iterative learning approach, and can self-adapting according to the initial feedback [17]. Table 1 and Figure 3A introduce and quickly explain common ML algorithms reviewed in this article. Based on different ML algorithms, several ML models with different functions have been developed so far. It is important to note that an optimal ML model cannot be easily developed with a limited dataset. Instead, a satisfactory ML model should be constructed in two phases: the model is developed in the training phase and then its performance is assessed in the testing phase [18] (Figure 3B).

In order to evaluate the performance of trained ML models, several reasonable evaluation indicators must be used. Generally, the ML model selects different evaluation indicators according to the different classification and regression tasks. In classification, the evaluation indicators are often accuracy, false positive rate, false negative rate, sensitivity (recall), specificity, precision, F1-score, C-index (concordance index), receiver operating characteristic curve and the area underneath it (AUC). The regression tasks focus on the difference between the predicted and true value. Therefore, the evaluation indicators include mean square error, root mean square error, mean absolute error, and median absolute deviation.

Although ML technology is continuously growing in the medical field, its application is greatly limited due to issues related to the availability of adequate data (e.g. text, numbers, images), experiments and methods, and ethics [14, 15]. Inaccurate or missing data can cause serious problems, leading to incorrect model structure and biased conclusions. The imbalance and sparsity of categories in medical data can also limit ML application. Therefore, repeated experiments need to be performed and different ML methods should be explored for addressing medical challenges. Experimental design and replication, model selection, model generalization, and model interpretability are crucial aspects of applying ML techniques [19]. A good experimental design can reduce experimental errors and give more accurate conclusions. Model selection is one process of finding a solution to the research problem, but there are currently no standards to guard against model misuse or abuse. ML can also improve model generalizability to ensure more accurate prediction of future cases, but how this is best done requires further study. Interpretability of a model makes it more relevant to medical decision making, but most data-driven ML techniques remain unexplored. Another challenge of using AI/ML is to ensure ethics and eliminate prejudice during their application [20]. Ethical problems can arise due to problems with optimization, prediction, or classification, which can lead to inequality on sensitive issues or to violations of privacy. Research should not only build ML models but also resolve ethical issues associated with data use and interpretation. Despite these current limitations, $\mathrm{AI} / \mathrm{ML}$ techniques are needed in the medical field due to the special ability to efficiently analyze and integrate large and heterogeneous data.
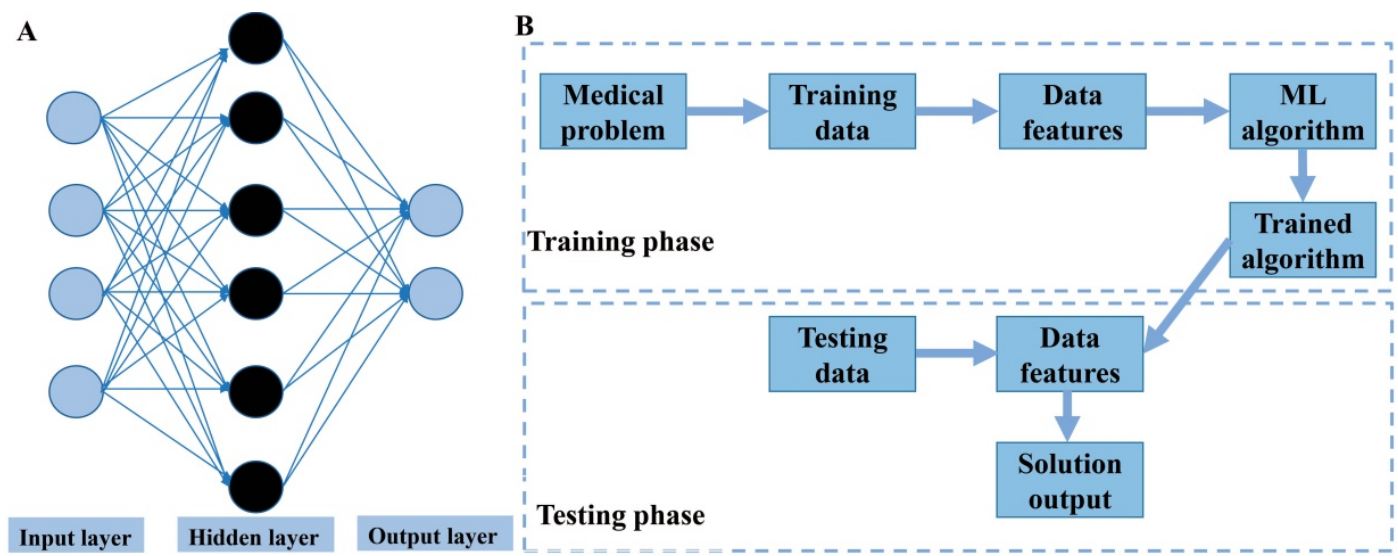

Figure 3. Overview of machine learning. A. Illustration of an artificial neural network algorithm. The structure of artificial neural network includes three main layers, namely input layer, hidden layer and output layer. The input layer represents the features extracted from data, which are then integrated by the hidden layer (one or more) to obtain transformed features. Finally, the transformed features are used by the output layer to predict the outcome. B. Common paths for training and testing machine learning model in medicine. 
Table 1. Summary of common machine learning algorithms

\begin{tabular}{|c|c|c|}
\hline $\begin{array}{l}\text { Type of machine } \\
\text { learning algorithm }\end{array}$ & Description & $\begin{array}{l}\text { References describing } \\
\text { applications }\end{array}$ \\
\hline $\begin{array}{l}\text { Natural language } \\
\text { processing }\end{array}$ & $\begin{array}{l}\text { Natural language processing is a general term for a series of technical methods. It can be divided into } \\
\text { natural language understanding (NLU) and natural language generation (NLG). NLU focuses on how to } \\
\text { understand text, while NLG focuses on how to generate natural text after understanding the text. }\end{array}$ & [23-25] \\
\hline K nearest neighbor & $\begin{array}{l}\text { K nearest neighbor is a type of instance-based learning algorithm, and the training process simply } \\
\text { memorize the training data. It categorizes the sample according to the similarity. The similarity is } \\
\text { calculated using measures such as Euclidean distance and Hamming distance. }\end{array}$ & $\begin{array}{l}{[27,28,52],[67,78,79]} \\
{[94,102,104]}\end{array}$ \\
\hline Random forest & $\begin{array}{l}\text { Random forest is an ensemble learning method. It contains multiple decision trees and integrates these } \\
\text { decision trees to category of data. The size of trees and the number of variables usually determine the } \\
\text { performance of model. }\end{array}$ & $\begin{array}{l}{[27,28,30],[47,48,59]} \\
{[65-67,74,79],[90,99,101]} \\
{[104,107,109]}\end{array}$ \\
\hline $\begin{array}{l}\text { Support vector } \\
\text { machine }\end{array}$ & $\begin{array}{l}\text { Support vector machine is usually used for classification and regression. It learns the optimal hyperplane } \\
\text { to classify data. Generally, it has low misclassification error and scale well to high-dimensional data. } \\
\text { However, selecting the optimal kernel function is essential. }\end{array}$ & $\begin{array}{l}{[28,32,35],[52,59,66-68]} \\
{[75,78,79],[95,99,102]} \\
{[103,104,108]}\end{array}$ \\
\hline $\begin{array}{l}\text { Artificial neural } \\
\text { network }\end{array}$ & $\begin{array}{l}\text { This is a kind of hierarchical nonlinear mapping network based on neurons and activation functions. Its } \\
\text { structure includes three main parts, namely input layer, hidden layer and output layer. This structure is } \\
\text { used to analyze variables in order to predict an outcome. The primary limitation is the underlying } \\
\text { model's lack of transparency. }\end{array}$ & {$[32,53-56],[62,69,79],[94,102]$} \\
\hline Latent class analysis & $\begin{array}{l}\text { Latent class analysis is a statistically principled technique that is used in factor analysis, cluster analysis, } \\
\text { and regression. It is to explain and estimate the association between manifest indicators by latent class } \\
\text { variables. This method suits to classify subgroups in large and heterogeneous data. }\end{array}$ & {$[40-44,50],[51,82]$} \\
\hline K-means & $\begin{array}{l}\text { This method divides the dataset into K clusters, and each cluster is represented by the average value of } \\
\text { all samples in the cluster, which is called the "centroid". K-means clustering is easy to interpret and } \\
\text { computationally efficient. However, the number of clusters needs to be prespecified. }\end{array}$ & {$[46,84,86],[88]$} \\
\hline Logistic regression & $\begin{array}{l}\text { Logistic regression estimates the probability of a binary classification problem. The dependent variable } \\
\text { of it obeys the Bernoulli distribution, and nonlinear factors are introduced through the Sigmoid function. }\end{array}$ & $\begin{array}{l}{[47,59,60],[66-68,78,79]} \\
{[95,99,102],[104,107,108]}\end{array}$ \\
\hline Decision tree & $\begin{array}{l}\text { Decision tree creates a series of decision rules to predict categorical and continuous outcomes based on } \\
\text { input variables. It contains three main parts: a root node, leaf nodes and branches. Decision tree is easy to } \\
\text { understanding, but unstable and prone to overfitting. }\end{array}$ & $\begin{array}{l}{[47,49,60],[67,68,78]} \\
{[79,97,100],[102]}\end{array}$ \\
\hline Lasso regression & $\begin{array}{l}\text { Lasso regression is a linear regression method using L1-regularization. L1-regularization can compress } \\
\text { the coefficients of variables and change some coefficients to zero, so as to achieve the purpose of variable } \\
\text { selection. }\end{array}$ & {$[48,59,98]$} \\
\hline Naïve Bayes & $\begin{array}{l}\text { Naïve Bayes is a classification algorithm based on Bayes' theorem, which is suitable for scenarios where } \\
\text { variables are independent of each other. It is relatively simple and has good performance in the presence } \\
\text { of noise, missing data, and irrelevant variables. }\end{array}$ & {$[64,67,68],[79,104]$} \\
\hline
\end{tabular}

\section{$\mathrm{AI} / \mathrm{ML}$ and asthma}

\section{Application of $\mathrm{Al} / \mathrm{ML}$ to asthma screening and diagnosis}

As a heterogeneous disease, asthma is often under- or overdiagnosed, especially in poor areas. In fact, almost $20-73 \%$ of cases remain undiagnosed, while about $30-35 \%$ of people diagnosed with asthma do not actually have the condition [21, 22].

To address this issue, EHRs and Predetermined Asthma Criteria were used in a retrospective birth cohort study to develop for the first time a natural language processing algorithm for pediatric asthma diagnosis with high sensitivity (97\%), specificity $(95 \%)$, as well as positive $(90 \%)$ and negative $(98 \%)$ predictive values. The test cohort of this study consisted by 497 children, among whom the asthma prevalence was $31 \%$. The application of the same algorithm to records from 497 children (median age, 2.3 years) at another hospital showed similar sensitivity (92\%), specificity (96\%), and positive (89\%) and negative $(97 \%)$ predictive values, confirming the algorithm's efficiency in diagnosing pediatric asthma in an external EHR system. However, the algorithm should be further validated on an adult cohort [23, 24] (Table 2). In another cross-sectional study, an ML model based on natural language processing algorithm was also developed by mining EHRs to automatically screen pediatric patients who met the Asthma Predictive Index criteria for asthma diagnosis. A total of 427 subjects with an average age of 5.3 years were enrolled in the test phase, and the sensitivity, specificity, and positive and negative predictive values of the ML model reached $86 \%, 98 \%$, $88 \%$, and $98 \%$, respectively [25]. These results suggest that ML models based on natural language processing can be used to identify pediatric patients with undiagnosed asthma. In addition, an artificial neural network model based on 13 clinical characteristics was developed using clinical findings from EHRs, which was able to identify $100 \%$ asthma patients among 254 individuals [26].

Although spirometry and bronchial provocation tests are increasingly available, they require the full cooperation of patients and cannot confirm correct diagnosis of asthma. Therefore, the non-invasive forced oscillation technique, which does not require patient cooperation, was combined with four ML algorithms (k-nearest neighbor, random forest, decision trees, and a feature-based dissimilarity space classifier) to produce ML classifiers that serve as a useful and portable tool for diagnosing asthma airway obstruction [27]. Among the four algorithms, 
k-nearest neighbor led to the highest AUC of 0.91 . Further research combining the forced oscillation technique with ML algorithms (k-nearest neighbor, random forest, AdaBoost with decision trees, and support vector machine) resulted in several novel classifiers that achieved AUC $\geq 0.9$ for the differential diagnosis of patients with asthma or restrictive respiratory diseases in 97 individuals. However, the results should be further verified on an external dataset [28].

Table 2. Machine learning studies on asthma

\begin{tabular}{|c|c|c|c|c|c|c|c|}
\hline Reference & Category & Study population & ML algorithms & Input features & $\begin{array}{l}\text { Studied } \\
\text { outcome }\end{array}$ & Results & Critical appraisal of the study \\
\hline $\begin{array}{l}\text { Wi CI, } 2017 \\
{[23]}\end{array}$ & $\begin{array}{l}\text { Screening and } \\
\text { diagnosis }\end{array}$ & $\begin{array}{l}927 \text { children: } \\
\text { training cohort }=430 \\
\text { test } \text { cohort }=497\end{array}$ & NLP & Clinical (EMRs) & $\begin{array}{l}\text { Pediatric } \\
\text { asthmatic } \\
\text { subjects or not }\end{array}$ & $\begin{array}{l}\text { Sensitivity }=97 \%, \\
\text { specificity }=95 \%, \text { positive } \\
\text { predictive value }=90 \%, \\
\text { negative predictive } \\
\text { value }=98 \%\end{array}$ & $\begin{array}{l}\text { Pros: use of electronic medical } \\
\text { records } \\
\text { Cons: single internal electronic } \\
\text { medical record system }\end{array}$ \\
\hline $\begin{array}{l}\text { Wi CI, } 2018 \\
{[24]}\end{array}$ & $\begin{array}{l}\text { Screening and } \\
\text { diagnosis }\end{array}$ & $\begin{array}{l}595 \text { children: } \\
\text { training cohort }=298 \\
\text { test cohort }=297\end{array}$ & NLP & Clinical (EHR) & $\begin{array}{l}\text { Pediatric } \\
\text { asthmatic } \\
\text { subjects or not }\end{array}$ & $\begin{array}{l}\text { Sensitivity }=92 \%, \\
\text { specificity }=96 \%, \text { positive } \\
\text { predictive value }=89 \%, \\
\text { negative predictive } \\
\text { value }=97 \%\end{array}$ & $\begin{array}{l}\text { Pros: use of an external electronic } \\
\text { medical records system } \\
\text { Cons: has not yet been validated on } \\
\text { an adult cohort }\end{array}$ \\
\hline $\begin{array}{l}\text { Kaur H, } \\
2018[25]\end{array}$ & $\begin{array}{l}\text { Screening and } \\
\text { diagnosis }\end{array}$ & $\begin{array}{l}514 \text { children: } \\
\text { training cohort }=87 \\
\text { test cohort }=427\end{array}$ & NLP & Clinical (EHR) & $\begin{array}{l}\text { Pediatric } \\
\text { asthmatic } \\
\text { subjects or not }\end{array}$ & $\begin{array}{l}\text { Sensitivity }=86 \%, \\
\text { specificity }=98 \%, \text { positive } \\
\text { predictive value }=88 \%, \\
\text { negative predictive } \\
\text { value }=98 \%\end{array}$ & $\begin{array}{l}\text { Pros: development of the first } \\
\text { algorithm to automatically extract } \\
\text { patients who meet the Asthma } \\
\text { Predictive Index criteria } \\
\text { Cons: relatively small sample }\end{array}$ \\
\hline $\begin{array}{l}\text { Alizadeh B, } \\
2015 \text { [26] }\end{array}$ & $\begin{array}{l}\text { Screening and } \\
\text { diagnosis }\end{array}$ & $\begin{array}{l}254 \text { subjects: } \\
\text { training cohort }=70 \% \\
\text { test cohort }=30 \%\end{array}$ & ANN & Clinical & $\begin{array}{l}\text { Asthmatic } \\
\text { subjects or not }\end{array}$ & Accuracy $=100 \%$ & $\begin{array}{l}\text { Pros: based on } 13 \text { clinical } \\
\text { characteristics used by physicians } \\
\text { to diagnose asthma } \\
\text { Cons: single data source and } \\
\text { relatively small sample }\end{array}$ \\
\hline $\begin{array}{l}\text { Amaral J, } \\
2017 \text { [27] }\end{array}$ & $\begin{array}{l}\text { Screening and } \\
\text { diagnosis }\end{array}$ & $\begin{array}{l}75 \text { stable asthma } \\
\text { patients: } 39 \text { with airway } \\
\text { obstruction and } 36 \\
\text { without }\end{array}$ & $\begin{array}{l}\text { KNN, RF, } \\
\text { ADAB, FDSC }\end{array}$ & $\begin{array}{l}\text { Forced oscillation } \\
\text { technique } \\
\text { parameters }\end{array}$ & $\begin{array}{l}\text { Airway } \\
\text { obstruction }\end{array}$ & $\begin{array}{l}\text { KNN reached the highest } \\
\text { accuracy range } \\
(\mathrm{AUC}=0.91)\end{array}$ & $\begin{array}{l}\text { Pros: use of the non-invasive forced } \\
\text { oscillation technique } \\
\text { Cons: the exact sensitivity and } \\
\text { specificity values are unknown }\end{array}$ \\
\hline $\begin{array}{l}\text { Amaral J, } \\
2020[28]\end{array}$ & $\begin{array}{l}\text { Screening and } \\
\text { diagnosis }\end{array}$ & $\begin{array}{l}97 \text { individuals: } \\
\text { controls }=20 \\
\text { asthmatic patients }=38 \\
\text { restrictive patients }=39\end{array}$ & $\begin{array}{l}\text { KNN, RF, } \\
\text { ADAB, SVM }\end{array}$ & $\begin{array}{l}\text { Forced oscillation } \\
\text { technique } \\
\text { parameters }\end{array}$ & $\begin{array}{l}\text { Asthmatic or } \\
\text { restrictive } \\
\text { respiratory } \\
\text { diseases } \\
\text { subjects }\end{array}$ & $\begin{array}{l}\text { All classifiers achieved } \\
\text { high accuracy (AUC } \geq 0.9)\end{array}$ & $\begin{array}{l}\text { Pros: differential diagnosis of } \\
\text { asthma and restrictive respiratory } \\
\text { diseases } \\
\text { Cons: single practice site and } \\
\text { relatively small sample }\end{array}$ \\
\hline $\begin{array}{l}\text { Zhan J, } \\
2020 \text { [29] }\end{array}$ & $\begin{array}{l}\text { Screening and } \\
\text { diagnosis }\end{array}$ & $\begin{array}{l}355 \text { asthma patients } \\
\text { and 1,480 healthy } \\
\text { individuals }\end{array}$ & $\begin{array}{l}\text { Mahalanobis- } \\
\text { Taguchi system }\end{array}$ & $\begin{array}{l}\text { Routine blood } \\
\text { biomarkers }\end{array}$ & $\begin{array}{l}\text { Asthmatic } \\
\text { subjects or not }\end{array}$ & $\begin{array}{l}\text { Accuracy }=94.15 \% \text { in } \\
\text { asthma patients and } \\
97.20 \% \text { in healthy } \\
\text { individuals }\end{array}$ & $\begin{array}{l}\text { Pros: diagnosis of asthma based on } \\
\text { routine blood biomarkers } \\
\text { Cons: a complete blood reference } \\
\text { space is required to more accurately } \\
\text { identify asthma patients }\end{array}$ \\
\hline $\begin{array}{l}\text { Sinha A, } \\
2017[30]\end{array}$ & $\begin{array}{l}\text { Screening and } \\
\text { diagnosis }\end{array}$ & $\begin{array}{l}89 \text { asthmatic subjects } \\
\text { and } 20 \text { healthy controls }\end{array}$ & RF & $\begin{array}{l}\text { Nuclear magnetic } \\
\text { resonance spectra } \\
\text { of exhaled breath } \\
\text { condensate }\end{array}$ & $\begin{array}{l}\text { Asthmatic } \\
\text { subjects or not }\end{array}$ & $\begin{array}{l}\text { Sensitivity }=80 \%, \\
\text { specificity }=75 \%\end{array}$ & $\begin{array}{l}\text { Pros: advocated the use of exhaled } \\
\text { breath condensate spectral } \\
\text { signatures } \\
\text { Cons: did not actually measure any } \\
\text { metabolites }\end{array}$ \\
\hline $\begin{array}{l}\text { Islam MA, } \\
2018[32]\end{array}$ & $\begin{array}{l}\text { Screening and } \\
\text { diagnosis }\end{array}$ & $\begin{array}{l}60 \text { subjects: } \\
\text { normal }=30 \\
\text { asthma patients }=30\end{array}$ & ANN, SVM & $\begin{array}{l}\text { Clinical (lung } \\
\text { sounds) }\end{array}$ & $\begin{array}{l}\text { Normal or } \\
\text { asthmatic } \\
\text { subjects }\end{array}$ & $\begin{array}{l}\text { Accuracy }=89.2( \pm 3.87) \% \\
\text { in ANN and } 93.3( \pm 3.10) \% \\
\text { in SVM }\end{array}$ & $\begin{array}{l}\text { Pros: used lung respiratory sound } \\
\text { signals } \\
\text { Cons: did not collect respiratory } \\
\text { sounds of both upper and lower } \\
\text { lung }\end{array}$ \\
\hline $\begin{array}{l}\text { Singh OP, } \\
2018[34]\end{array}$ & $\begin{array}{l}\text { Screening and } \\
\text { diagnosis }\end{array}$ & $\begin{array}{l}\text { non-asthmatic }=30 \\
\text { asthmatic }=43\end{array}$ & $\begin{array}{l}\text { SVM, KNN, } \\
\text { NB }\end{array}$ & $\begin{array}{l}\text { Respired carbon } \\
\text { dioxide waveform }\end{array}$ & $\begin{array}{l}\text { Asthmatic } \\
\text { subjects or not }\end{array}$ & $\begin{array}{l}\text { Accuracy }=94.52 \% \text {, } \\
\text { sensitivity }=97.67 \% \text {, and } \\
\text { specificity }=90 \% \text { in SVM }\end{array}$ & $\begin{array}{l}\text { Pros: non-invasive, } \\
\text { patient-independent method based } \\
\text { on simple signal processing } \\
\text { algorithm to screen for asthma } \\
\text { Cons: relatively small sample }\end{array}$ \\
\hline $\begin{array}{l}\text { Tomita K, } \\
2019[35]\end{array}$ & $\begin{array}{l}\text { Screening and } \\
\text { diagnosis }\end{array}$ & $\begin{array}{l}566 \text { adult out-patients } \\
\text { (367 asthma patients) }\end{array}$ & SVM, DNN & $\begin{array}{l}\text { Clinical, Lung } \\
\text { function test, } \\
\text { Bronchial } \\
\text { challenge test }\end{array}$ & $\begin{array}{l}\text { Adult } \\
\text { asthmatic } \\
\text { subjects or not }\end{array}$ & $\begin{array}{l}\text { Accuracy }=98 \% \text { in DNN } \\
\text { and } 82 \% \text { in SVM }\end{array}$ & $\begin{array}{l}\text { Pros: models based on symptoms, } \\
\text { physical signs and objective tests } \\
\text { Cons: single practice site }\end{array}$ \\
\hline $\begin{array}{l}\text { Couto M, } \\
2015[40]\end{array}$ & $\begin{array}{l}\text { Classification } \\
\text { and assessment }\end{array}$ & $\begin{array}{l}\text { asthmatic athletes }=150 \\
\text { healthy athletes }=129 \\
\text { athletes with other } \\
\text { pathologic conditions = } \\
45\end{array}$ & LCA & $\begin{array}{l}\text { Clinical (athletes' } \\
\text { records) }\end{array}$ & $\begin{array}{l}\text { Asthmatic } \\
\text { phenotypes }\end{array}$ & $\begin{array}{l}\text { Two phenotypes: atopic } \\
\text { asthma and sports } \\
\text { asthma }\end{array}$ & $\begin{array}{l}\text { Pros: identification of asthmatic } \\
\text { athlete phenotypes } \\
\text { Cons: need to be validated by larger } \\
\text { clinical interventional trials }\end{array}$ \\
\hline $\begin{array}{l}\text { Chen Q, } \\
2012[41]\end{array}$ & $\begin{array}{l}\text { Classification } \\
\text { and assessment }\end{array}$ & 689 asthma children & LCA, BIC & $\begin{array}{l}\text { Clinical } \\
\text { (questionnaire } \\
\text { data) }\end{array}$ & $\begin{array}{l}\text { Asthmatic } \\
\text { phenotypes }\end{array}$ & $\begin{array}{l}\text { Four phenotypes: } \\
\text { never/infrequent, early- } \\
\text { transient, early- } \\
\text { persistent, and late-onset }\end{array}$ & $\begin{array}{l}\text { Pros: identification of phenotypes } \\
\text { based on wheeze } \\
\text { Cons: some children could not } \\
\text { provide precision data }\end{array}$ \\
\hline $\begin{array}{l}\text { Weinmayr } \\
\text { G, } 2013[42]\end{array}$ & $\begin{array}{l}\text { Classification } \\
\text { and assessment }\end{array}$ & $>4,000$ asthma children & LCA, BIC & $\begin{array}{l}\text { Clinical } \\
\text { (questionnaire), } \\
\text { Bronchial } \\
\text { hyperresponsiven } \\
\text { ess }\end{array}$ & $\begin{array}{l}\text { Childhood } \\
\text { asthma } \\
\text { phenotypes }\end{array}$ & $\begin{array}{l}\text { Seven phenotypes: one } \\
\text { corresponding to healthy } \\
\text { children; three related to } \\
\text { wheeze; three related to } \\
\text { congestion and } \\
\text { coughed-up phlegm }\end{array}$ & $\begin{array}{l}\text { Pros: identification of phenotypes } \\
\text { according to respiratory symptoms } \\
\text { Cons: recall bias }\end{array}$ \\
\hline
\end{tabular}




\begin{tabular}{|c|c|c|c|c|c|c|c|}
\hline Reference & Category & Study population & ML algorithms & Input features & $\begin{array}{l}\text { Studied } \\
\text { outcome }\end{array}$ & Results & Critical appraisal of the study \\
\hline $\begin{array}{l}\text { Bochenek } \\
\text { G, } 2014 \text { [43] }\end{array}$ & $\begin{array}{l}\text { Classification } \\
\text { and assessment }\end{array}$ & $\begin{array}{l}201 \text { aspirin-exacerbated } \\
\text { respiratory disease } \\
\text { patients }\end{array}$ & LCA & $\begin{array}{l}\text { Clinical } \\
\text { (questionnaire, } \\
\text { spirometry, blood } \\
\text { eosinophilia, } \\
\text { urinary LTE4 } \\
\text { concentrations) }\end{array}$ & $\begin{array}{l}\text { Subphenotypes } \\
\text { within AERD } \\
\text { phenotype }\end{array}$ & $\begin{array}{l}\text { Four subphenotypes: } \\
\text { asthma with a moderate } \\
\text { course; asthma with a } \\
\text { mild course; asthma with } \\
\text { a severe course; poorly } \\
\text { controlled } \\
\text { asthma with frequent and } \\
\text { severe exacerbations }\end{array}$ & $\begin{array}{l}\text { Pros: identification of } \\
\text { aspirin-exacerbated respiratory } \\
\text { disease phenotypes } \\
\text { Cons: LCA stability over time not } \\
\text { established }\end{array}$ \\
\hline $\begin{array}{l}\text { Havstad S, } \\
2014[44]\end{array}$ & $\begin{array}{l}\text { Classification } \\
\text { and assessment }\end{array}$ & $\begin{array}{l}594 \text { asthma children ( } 2 \\
\text { years old) }\end{array}$ & LCA & $\begin{array}{l}\text { Serum IgE data on } \\
10 \text { allergens }\end{array}$ & $\begin{array}{l}\text { Atopic asthma } \\
\text { phenotypes }\end{array}$ & $\begin{array}{l}\text { Four phenotypes: low to } \\
\text { no sensitization; highly } \\
\text { sensitized; milk and egg } \\
\text { dominated; peanut and } \\
\text { inhalant(s)/no milk }\end{array}$ & $\begin{array}{l}\text { Pros: examination of a more } \\
\text { recently born, younger, and racially } \\
\text { mixed cohort } \\
\text { Cons: lack of additional } \\
\text { information on lung function, } \\
\text { cytokines, and eosinophils }\end{array}$ \\
\hline $\begin{array}{l}\text { Ross MK, } \\
2018 \text { [45] }\end{array}$ & $\begin{array}{l}\text { Classification } \\
\text { and assessment }\end{array}$ & $\begin{array}{l}\text { 1,019 children from the } \\
\text { CAMP study and } 669 \\
\text { children from the } \\
\text { ACRN/CARE dataset }\end{array}$ & $\mathrm{PP}$ & Clinical & $\begin{array}{l}\text { Pediatric } \\
\text { asthma } \\
\text { phenotypes }\end{array}$ & $\begin{array}{l}\text { Four phenotypes: } \\
\text { allergic-not-obese, } \\
\text { obese-not-allergic, } \\
\text { allergic-and-obese, and } \\
\text { not-obese-not-allergic }\end{array}$ & $\begin{array}{l}\text { Pros: discovery of more detailed } \\
\text { predictive features for long-term } \\
\text { asthma control other than the } \\
\text { current control state } \\
\text { Cons: elimination of some features } \\
\text { due to missing data }\end{array}$ \\
\hline $\begin{array}{l}\text { Wu W, } \\
2019[46]\end{array}$ & $\begin{array}{l}\text { Classification } \\
\text { and assessment }\end{array}$ & $\begin{array}{l}346 \text { adult asthma in the } \\
\text { Severe Asthma } \\
\text { Research Program }\end{array}$ & $\begin{array}{l}\text { Multiple-kerne } \\
1 \text { k-means }\end{array}$ & $\begin{array}{l}\text { Clinical, } \\
\text { physiological, } \\
\text { inflammatory, } \\
\text { demographic }\end{array}$ & $\begin{array}{l}\text { Asthma control } \\
\text { state }\end{array}$ & $\begin{array}{l}\text { Four phenotypes: clusters } \\
1 \text { and 2: young modestly } \\
\text { corticosteroid responsive } \\
\text { allergic asthmatics with } \\
\text { relatively normal lung } \\
\text { function; cluster 3: late } \\
\text { onset asthmatics with low } \\
\text { lung function; cluster 4: } \\
\text { primarily young obese } \\
\text { females with severe } \\
\text { airflow limitation }\end{array}$ & $\begin{array}{l}\text { Pros: identification of phenotypes } \\
\text { based on corticosteroid responses } \\
\text { Cons: limited to a single dose of } \\
\text { systemic corticosteroid (without } \\
\text { placebo) and a single point in time }\end{array}$ \\
\hline $\begin{array}{l}\text { Prosperi } \\
\text { MC, } 2014 \\
{[47]}\end{array}$ & $\begin{array}{l}\text { Classification } \\
\text { and assessment }\end{array}$ & 554 asthma adults & $\mathrm{LR}, \mathrm{RF}, \mathrm{DT}, \mathrm{AB}$ & Clinical, genetic & $\begin{array}{l}\text { Current } \\
\text { asthma, } \\
\text { wheeze, } \\
\text { eczema }\end{array}$ & $\begin{array}{l}\text { Optimal AUC }=0.84,0.76 \\
\text { and } 0.64 \text { for asthma, } \\
\text { wheeze, and eczema, } \\
\text { respectively }\end{array}$ & $\begin{array}{l}\text { Pros: integrated genomics } \\
\text { information } \\
\text { Cons: genetic analysis was } \\
\text { restricted to candidate genes }\end{array}$ \\
\hline $\begin{array}{l}\text { Krautenbac } \\
\text { her N, } 2019 \\
{[48]}\end{array}$ & $\begin{array}{l}\text { Classification } \\
\text { and assessment }\end{array}$ & $\begin{array}{l}260 \text { individuals: } \\
\text { healthy children }=43 \% \text {, } \\
\text { mild-to-moderate, } \\
\text { allergic asthmatics }= \\
47 \%, \text { nonallergic } \\
\text { asthmatics }=11 \%\end{array}$ & $\begin{array}{l}\text { Lasso } \\
\text { regression, } \\
\text { elastic net, RF }\end{array}$ & $\begin{array}{l}\text { Genetic, } \\
\text { immunological, } \\
\text { environmental }\end{array}$ & $\begin{array}{l}\text { Asthma } \\
\text { phenotypes }\end{array}$ & $\begin{array}{l}\text { AUC for three classes of } \\
\text { phenotypes }=0.81\end{array}$ & $\begin{array}{l}\text { Pros: identification of three } \\
\text { important genes for classifying } \\
\text { childhood asthma phenotypes: } \\
\text { PKN2, PTK2 and ALPP } \\
\text { Cons: should be validated in other } \\
\text { cohort studies }\end{array}$ \\
\hline $\begin{array}{l}\text { Williams-D } \\
\text { e } \\
\text { Vane CR, } \\
2013[49]\end{array}$ & $\begin{array}{l}\text { Classification } \\
\text { and assessment }\end{array}$ & 205 individuals & DT & $\begin{array}{l}\text { Clinical, genetic, } \\
\text { demographic }\end{array}$ & $\begin{array}{l}\text { Asthma } \\
\text { endotypes }\end{array}$ & $\begin{array}{l}\text { Decision tree-based } \\
\text { methods were useful } \\
\text { tools for identifying } \\
\text { asthma endotypes }\end{array}$ & $\begin{array}{l}\text { Pros: integrated data to identify } \\
\text { asthma endotypes } \\
\text { Cons: should be validated in } \\
\text { external data }\end{array}$ \\
\hline $\begin{array}{l}\text { Siroux V, } \\
2014 \text { [50] }\end{array}$ & $\begin{array}{l}\text { Classification } \\
\text { and assessment }\end{array}$ & 3,001 asthmatic adults & LCA & $\begin{array}{l}\text { Clinical } \\
\text { (questionnaire } \\
\text { data), genetic }\end{array}$ & $\begin{array}{l}\text { Asthma } \\
\text { phenotypes }\end{array}$ & $\begin{array}{l}\text { Four phenotypes: } \\
\text { inactive/mild nonallergic } \\
\text { asthma, inactive/mild } \\
\text { allergic asthma, active } \\
\text { allergic asthma, and } \\
\text { active adult-onset } \\
\text { nonallergic asthma }\end{array}$ & $\begin{array}{l}\text { Pros: large sample of asthmatic } \\
\text { adults } \\
\text { Cons: lack of formal replication of } \\
\text { the genetic association signals }\end{array}$ \\
\hline $\begin{array}{l}\text { Mäkikyrö } \\
\text { EM, } \\
2017 \text { [51] }\end{array}$ & $\begin{array}{l}\text { Classification } \\
\text { and assessment }\end{array}$ & 1,995 asthma subjects & LCA & $\begin{array}{l}\text { Clinical } \\
\text { (questionnaire } \\
\text { data), } \\
\text { asthma-related } \\
\text { healthcare use }\end{array}$ & $\begin{array}{l}\text { Asthma } \\
\text { phenotypes }\end{array}$ & $\begin{array}{l}\text { Four subtypes for } \\
\text { women: mild asthma, } \\
\text { moderate asthma, } \\
\text { unknown severity, and } \\
\text { severe asthma. } \\
\text { Three subtypes for men: } \\
\text { mild asthma, unknown } \\
\text { severity, and severe } \\
\text { asthma. }\end{array}$ & $\begin{array}{l}\text { Pros: development of a simpler way } \\
\text { to categorize asthmatic subtypes } \\
\text { Cons: did not test the population } \\
\text { for biomarkers and form } \\
\text { endotypes; did not verify the } \\
\text { subtypes with full scale lung } \\
\text { function testing }\end{array}$ \\
\hline $\begin{array}{l}\text { Nabi FG, } \\
2019 \text { [52] }\end{array}$ & $\begin{array}{l}\text { Classification } \\
\text { and assessment }\end{array}$ & 55 asthma patients & $\begin{array}{l}\text { Ensemble, } \\
\text { SVM, KNN }\end{array}$ & Wheeze sounds & $\begin{array}{l}\text { Asthma } \\
\text { severity }\end{array}$ & $\begin{array}{l}\text { The best positive } \\
\text { predictive value for the } \\
\text { mild, moderate, and } \\
\text { severe samples were } 95 \% \\
\text { (ensemble), } 88 \% \\
\text { (ensemble) and } 90 \% \\
\text { (SVM), respectively. }\end{array}$ & $\begin{array}{l}\text { Pros: classified wheeze sounds of } \\
\text { asthmatic patients according to } \\
\text { severity } \\
\text { Cons: relatively small sample }\end{array}$ \\
\hline $\begin{array}{l}\text { Moustris } \\
\mathrm{KP}, 2012 \\
{[53]}\end{array}$ & $\begin{array}{l}\text { Management } \\
\text { and monitoring }\end{array}$ & 3,602 children & ANN & $\begin{array}{l}\text { Meteorological } \\
\text { and ambient air } \\
\text { pollution data }\end{array}$ & $\begin{array}{l}\text { Childhood } \\
\text { asthma } \\
\text { admissions }\end{array}$ & $\begin{array}{l}\text { Index of } \\
\text { Agreement }=0.837 \\
\text { Coefficient of } \\
\text { determination }=0.528\end{array}$ & $\begin{array}{l}\text { Pros: predicted the childhood } \\
\text { asthma admission based on the } \\
\text { bioclimatic and air pollution } \\
\text { Cons: some environmental factors } \\
\text { had not been included, such as } \\
\text { relative humidity }\end{array}$ \\
\hline $\begin{array}{l}\text { Messinger } \\
\text { AI, } 2019 \\
{[54]}\end{array}$ & $\begin{array}{l}\text { Management } \\
\text { and monitoring }\end{array}$ & $\begin{array}{l}128 \text { asthmatic children: } \\
\text { training set }=102 \\
\text { testing set }=26\end{array}$ & ANN & $\begin{array}{l}\text { Demographic, } \\
\text { clinical (EHR) }\end{array}$ & $\begin{array}{l}\text { Respiratory } \\
\text { score }\end{array}$ & $\begin{array}{l}\text { The performance of } \\
\text { pediatric-automated } \\
\text { asthma severity scores } \\
\text { was better than Pediatric } \\
\text { Asthma Score. }\end{array}$ & $\begin{array}{l}\text { Pros: pARS had the potential to } \\
\text { help standardize acute pediatric } \\
\text { asthma care in the PICU. } \\
\text { Cons: incomplete data from the } \\
\text { clinical record and sign database; a } \\
\text { single center study }\end{array}$ \\
\hline Xiang $Y$, & Management & 31,433 adult asthma & ANN & Clinical (EHR) & Asthma & AUC $=0.7003$ & Pros: a time-sensitive predictive \\
\hline
\end{tabular}




\begin{tabular}{|c|c|c|c|c|}
\hline Reference & Category & Study population & ML algorithms & Input features \\
\hline
\end{tabular}

$\begin{aligned} & \text { Studied } \\ & \text { outcome }\end{aligned}$
exacerbation

Critical appraisal of the study

model

Cons: some potential risk factors for asthma exacerbations might not be recorded or might even be incorrectly recorded

$\begin{array}{llll}\begin{array}{l}\text { Khatri KL, } \\ 2018[56]\end{array} & \begin{array}{l}\text { Management } \\ \text { and monitoring }\end{array} & \begin{array}{l}\text { Patients of visiting } \\ \text { emergency } \\ \text { departments in Dallas } \\ \text { County for respiratory } \\ \text { diseases }\end{array} & \text { ANN } \\ \text { Grunwell } & \begin{array}{l}\text { Management } \\ \text { JR, 2020 }\end{array} & \text { and monitoring } \\ {[57]} & & \end{array}$

$\mathrm{NN}$

\section{meteorological
and \\ environmental}

pollution data

Clinical, demographics

Asthma exacerbation

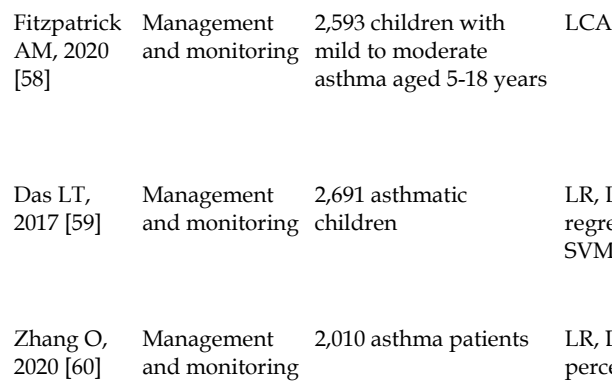

Zhang O, Management 2,010 asthma patients 2020 [60] and monitoring

LR, DT, NB perceptron algorithms

\section{Clinical, demographics, lung function test}

\section{Clinical (EHR)}

Emergency Lung function and rate

Emergency department visits

Daily monitoring Asthma data exacerbation

Search index, air admissions pollution data, weather data, historical Twitter data, Google search interests, environmental

data (between October 2013 and December 2013)

Finkelstein Management 7,001 records submitted NB, BN, SVM J, 2016 [64] and monitoring by adult asthma patients

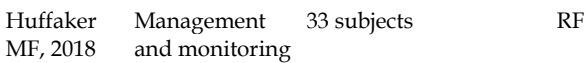
[65]

Luo L, 2020 Management Cost data of asthmatic [66] and monitoring patients

Khasha R, Management 96 asthma patients 2019 [67] and monitoring $\begin{array}{ll}\text { RF } & \text { Recorded } \\ \text { physiologic data }\end{array}$

LR, RF, SVM, Cost data classification regression tree, backpropagatio $\mathrm{n}$ neural network LR, XGBoost, Clinical, RF, DT, KNN, demographics, NB, SVM lung function test
Asthma admission

Emergency department visits

Daily

self-monitoring reports

Clinical,
demographics,
ung function test

Tsang K, Management 5,875 asthma patients 2020 [68] and monitoring

LR, NB, DT, mHealth data SVM

Hosseini Treatment SA, 2020 [69]

80 patients with mild or ANN
moderate allergic
asthma

\section{Clinical, immunologic hematologic,} symptoms occurred departmen
visits

Overall accuracy $=81.0 \%$ Pros: can serve as useful tool for peak demand prediction in emergency departments Cons: limited number of variables; primary diagnosis may not be accurate

The class of multiple Pros: prediction of exacerbation in sensitizations with school-age children partially reversible Cons: factors responsible for airflow limitation had the asthma exacerbations were not highest exacerbation risk adequately addressed by the study $(64.3 \%)$

Children who had Pros: large sample size of diverse multiple sensitizations and representative children across with partially reversible the United States airflow limitation had the Cons: model selection for LCA can highest exacerbation risk be subjective (52.5\%)

AUC $=0.86$ reached by Pros: based on electronic health LR records (EHRs)

Cons: record of emergency department visits to one medical center

AUC $=0.85$, sensitivity $=$ Pros: use of a large international $90 \%$, and specificity $=\quad$ dataset to detect severe asthma $83 \%$ reached by LR exacerbations

Cons: data were collected using paper diaries, which be inaccurate or fabricated

AUC $=0.832$

Pros: use of an easily accessible and daily updated daily search index Cons: data from a single geographical region

Pros: based on real-time environmental and internet-based data

Cons: data of emergency department visits from one hospital

Asthma BN model reached exacerbations sensitivity, specificity, and accuracy of $100 \%$

Pros: use of home telemonitoring data

Cons: the number of cases of asthma exacerbations was small Pros: showed that passive

The time period Sensitivity $=47.2 \%$, during which specificity $=96.3 \%$, onset of asthma accuracy $=87.4 \%$

Treatment cost AUC and sensitivity increase of $46.89 \%$ and $101.07 \%$, respectively physiologic monitoring can be used in the home to assess asthma control

Cons: small sample Pros: use of machine learning to predict high cost Cons: lack of analysis of low-frequency comorbidities

Control level Optimal accuracy $=91.66 \%$

Pros: developed a novel ensemble learning method for asthma control level detection Cons: limited factors affecting asthma control were included Pros: personalized algorithms to enhance asthma management Cons: self-reported data rather than objective measures

Pros: new machine learning model for the prediction of asthmatic drug effectiveness

Cons: relatively small sample

Abbreviations: $\mathrm{AB}, \mathrm{AdaBoost}$, $\mathrm{ADAB}, \mathrm{AdaBoost}$ with decision trees; $\mathrm{AERD}$, aspirin-exacerbated respiratory disease; $\mathrm{ANN}$, artificial neural networks; $\mathrm{AUC}$, area under the receiver operating characteristic curve; BN, Bayesian networks; BIC, Bayesian Information Criterion; DT, decision trees; DNN, deep neural network; EMRs, electronic medical records; EHR, electronic health records; FDSC, feature-based dissimilarity space classifier; KNN, k-nearest neighbor; LCA, latent class analysis; LR, logistic regression; NB, naïve Bayesian; NLP, natural language processing; PP, predictor pursuit; RF, random forest; SVM, support vector machine. 
Despite the lack of specific biomarkers for asthma, its diagnosis can be improved by combining multiple methods and clinical data. For instance, a novel AI system (Mahalanobis-Taguch) was developed based on ML algorithm and several biomarkers determined from routine blood samples, such as platelet distribution width, white blood cell count, and eosinophil count. This system was trained using data from 319 asthmatic patients, then validated in 35 asthmatic patients with a classification accuracy of $94.15 \%$ [29]. Further confirmation of the effectiveness of this AI system in clinical practice will simplify the diagnosis of asthma. In another study, a random forest classifier based on nuclear magnetic resonance spectroscopy of exhaled breath condensate was developed using the metabolome as the biomarker source [30]. The classifier differentiated asthma patients and healthy controls with $80 \%$ sensitivity and $75 \%$ specificity. However, the sample in the study ( $\mathrm{n}=109)$ was relatively small, and no actual metabolites were measured, suggesting that the method requires further validation.

A recent systematic review has also suggested that automated analysis of respiratory sounds by ML algorithms can be used for effective screening and diagnosis of respiratory diseases [31]. Indeed, multichannel lung respiratory sound signals derived from 30 asthmatic patients and 30 healthy controls were combined with artificial neural network or support vector machine classifiers for the diagnosis of asthma with respective accuracies of $89.2 \pm 3.87 \%$ and $93.3 \pm 3.10 \%$ [32]. Interestingly, this study did not rely on the presence of the typical wheezing asthmatic symptom as a sound signal. Future studies should collect respiratory sounds of both upper and lower lung lobes for further validation of the results.

Given the usefulness of end-tidal capnography for disease diagnosis, a non-invasive, patientindependent method to process carbon dioxide waveform signals was developed based on the support vector machine classifier to differentiate 30 non-asthmatic and 43 asthmatic patients. The average accuracy, sensitivity, and specificity of the algorithm reached $94.52 \%, 97.67 \%$ and $90 \%$, respectively, suggesting end-tidal capnography as an effective technique for asthma diagnosis [33, 34]. However, further validation of the results is required due to the small samples in those studies.

Recently, several classical ML algorithms, such as logistic regression analysis, support vector machine, and deep neural network, were compared for their diagnostic ability when based only on symptoms and physical signs, or when based on the combination of symptoms, physical signs, biochemical findings, lung function tests, and the bronchial provocation tests. That study included 566 adult outpatients and indicated that the deep neural network model was more accurate than other conventional ML tools, reaching an accuracy of $98 \%$ when symptoms, physical signs and objective tests were also used [35]. This study may be the first to report that AI can perform comparably to human experts for diagnosing asthma in adults. However, the results should be interpreted and generalized carefully, as different ML predictive models perform differently depending on the conditions.

\section{Application of Al/ML to the classification and assessment of asthma}

Asthma is a heterogeneous disease with multiple phenotypes and endotypes that must be properly distinguished for precise prevention and personalized treatment [36-38]. In clinical practice, spirometry and bronchial provocation tests are used to assess airflow limitation and hyperresponsiveness, allowing the identification of some asthma phenotypes, while eosinophil count analysis and fractional exhaled nitric oxide measurements can also be applied [39]. However, further research is still required to practically and accurately identify the asthma phenotypes.

Latent class analysis can generally fit a probabilistic model to a dataset of several variables such as asthma symptoms or allergy. Therefore, several recent studies have developed, verified, and applied ML-based latent class analysis for asthma classification, indicating its suitability for modelling data from symptomatic or asymptomatic asthma patients [40-44]. For instance, based on the data of athlete records that included respiratory symptoms, airway inflammation and hyperresponsiveness, allergic sensitization and lung function test, latent class analysis successfully identified two asthma phenotypes in a total of 150 elite asthmatic athletes who came from Portugal and Norway. The atopic asthma phenotype was defined by allergy symptoms, rhinitis, and high exhaled nitric oxide level, while the sports asthma phenotype was defined by exercise-induced respiratory symptoms and airway hyperresponsiveness, but no allergy [40]. The study also found that athletes who practiced water and winter sports were at higher risk of developing the sports asthma phenotype. The validation of this classification method using additional data sources or clinical interventional trials would significantly benefit the personalized treatment of asthmatic athletes.

A predictor pursuit algorithm based on clinical treatment and outcome data was also developed to analyze phenotypes of 1688 childhood asthma 
patients. Four phenotypes were identified with better $(\mathrm{P}<0.001)$ than traditional ML methods [45]. The study also found that nedocromil was better than budesonide in controlling asthma in children with obesity and allergy. A similar classification approach was later reported that focused mainly on the response of severe asthma patients to corticosteroids. Using an unsupervised ML approach (multiple-kernel k-means clustering), four phenotypes were identified in a total of 346 asthma patients. The greatest corticosteroid responsiveness was observed for patients with late-onset, poor lung function as well as high baseline eosinophilia, while the lowest responsiveness was observed for young, obese female patients with severe airflow limitation and mild eosinophilic inflammation [46]. Applying these methods to the timely and accurate classification of asthma patients will be a valuable reference for individualized treatment, especially for difficult-totreat asthma, while reducing the unnecessary use of corticosteroids and related complications.

Precision medicine is an emerging approach of medical science for disease diagnosis and treatment, while genomics is an important manner. In recent years, genetic data have been combined with other clinical information (e.g., demographic, laboratory, and environmental factors) within different ML algorithms to determine asthma phenotypes [47-50]. For example, 14 clinical features from 3001 adults with asthma, which included demography, medical history, respiratory symptoms, allergic characteristics, lung function test and bronchial hyperresponsiveness, were integrated with genomics data from previous analyses in order to differentiate asthma phenotypes. Four phenotypes were obtained using latent class analysis algorithm: inactive/mild nonallergic asthma (18\%), inactive/mild allergic asthma (37\%), active allergic asthma (27\%) and active adult-onset nonallergic asthma (18\%). This study also identified 15 single nucleotide polymorphisms associated with at least one these four asthma phenotypes, most of them were linked to the "active allergic asthma" phenotype [50]. Further research is needed to overcome the limitations of the in-house validation and small sample for genetic analysis, as well as to incorporate more factors and longitudinal data.

ML algorithms have also been used to classify asthma phenotypes according to the disease severity. In particular, latent class analysis was applied to questionnaire data included demographic and clinical features to classify female asthma patients into four phenotypes ("controlled, mild asthma", "partly controlled, moderate asthma", "uncontrolled asthma of unknown severity", and "uncontrolled, severe asthma") and male asthma patients into three phenotypes ("controlled, mild asthma", "poorly controlled asthma of unknown severity", and "partly controlled, severe asthma") [51]. Although the study provided a simpler method for identifying asthmatic phenotypes, there are still several limitations, such as the lack of formal verification of lung function testing. In a similar study, the correlation of wheeze sounds with asthmatic severity was analyzed in 55 asthmatic patients using three ML algorithms, including the ensemble, support vector machine and k-nearest neighbor. The ensemble algorithm showed better performance, and the wheeze sound was identified as a sensitive and specific predictor of asthma severity [52].

\section{Application of $\mathrm{Al} / \mathrm{ML}$ to the monitoring and management of asthma}

Asthma exacerbation and admission have a significant impact on the life quality and mortality of patients. Artificial neural networks have been extensively used to monitor and manage asthma exacerbation and admission [53-56]. For example, an artificial neural network was used to analyze clinical data and create an automated pediatric asthma severity score, which showed better performance than the pediatric asthma score and could therefore help manage pediatric asthma exacerbation in the pediatric intensive care unit [54]. Similarly, a retrospective cohort study of 31,433 adult asthma patients reported a time-sensitive predictive model based on an artificial neural network, which integrated clinical variables in the observed time window to predict asthma exacerbation [55]. In addition, a modified artificial neural network was applied to predict emergency department visits of asthma and COPD patients due to exacerbation. The developed ML model integrated several daily variables, including the number of emergency department visits as well as meteorological and environmental pollution data, reaching an overall accuracy of $81 \%$. Nevertheless, further studies should include other variables associated with the exacerbation of these diseases [56].

In recent studies, latent class analysis has been used to predict the exacerbation risk of asthma and the decline of lung function in school-age children [57, 58]. In the latter study, a dataset consisting of 19 demographic, clinical, and laboratory variables derived from 2,593 children with mild to moderate asthma was used, and the analysis identified allergy and lung function as the main predictors of exacerbation. A similar retrospective cohort study was also performed using EHRs from 2,691 asthmatic children. Among several ML methods, the multivariable logistic regression model proved to be the most accurate, with AUC $=0.86$ [59]. However, all 
data in that study came from a single medical center, and the multivariable logistic regression model could not be validated.

The application of four ML algorithms (logistic regression, decision tree, naïve Bayes, and perceptron algorithm) to predict severe exacerbations of asthma was recently reported based on daily monitoring data of 576 severe exacerbation events in 2,010 asthma patients. The logistic regression-based model yielded an optimal AUC of 0.85 , sensitivity of $90 \%$ and specificity of $83 \%$ [60]. Given the close correlation between severe exacerbations and asthma mortality, the model may be useful to physicians as a reference, but the research data were collected from paper diaries that may be inaccurate.

In order to assess the predictability of an Internet search index for asthma admission, an ML-based prediction model (XGBoost) was developed by combining search index and data, such as air pollution, weather, and previous admission events, yielding a maximum AUC of 0.832. However, the model performance should be further validated in other geographical regions [61]. In a similar approach, an artificial neural network model was applied to predict, in real time, asthma-related emergency department visits using environmental and social media data, such Google searches and Twitter [62]. The model accuracy was $70 \%$, making it suitable for early intervention in asthma patients to avoid exacerbation. A growing number of studies have also used electronic devices to manage, monitor, and follow asthma patients in real time [63-65]. For example, several ML algorithms (naïve Bayesian classifier, adaptive Bayesian network, and support vector machine) were used to analyze telemonitoring data from laptops at home in order to predict asthma exacerbation in a timely fashion. The sensitivity, specificity, and accuracy of the adaptive Bayesian network model reached $100 \%$, but the study was limited by the low number of exacerbations in the collected data [64]. Another study used a contactless bed sensor to capture physiological and environmental data for the early detection of asthma exacerbation in children. Using a random forest classification model, an accuracy of $87.4 \%$ was achieved [65].

Moreover, a comorbidity portfolio model was also designed based on ML algorithms to improve the prediction of asthma treatment costs over traditional approaches [66]. The study found that a combination of cardiovascular and other respiratory diseases was a major risk for increased treatment costs in asthmatic patients. This study provides an important perspective on controlling asthma expenses in light of the high financial burden of asthma worldwide and continuing concern about treatment costs.

Successful monitoring of asthma control levels also plays a significant role in the treatment of the disease. Therefore, physicians' expertise was combined with an ensemble ML algorithm to detect asthma control. The optimal accuracy of the model was $91.66 \%$ and, although the study included relatively few factors affecting asthma control, the model could help clinicians develop timely treatment plans [67]. Based on these findings, several common supervised ML algorithms were further used to analyze asthmatic monitoring data from 5,875 patients enrolled in the Asthma Mobile Health Study. Both logistic regression and naïve Bayes-based classifiers identified the control level with high accuracy (AUC $>$ 0.87) [68], suggesting that this method could serve as a valuable reference for the treatment of asthma in clinical practice. However, these models should be further validated using more diverse data, preferably data based on objective measures rather than self-report.

\section{Application of $\mathrm{Al} / \mathrm{ML}$ to the treatment of asthma}

Despite the wide variety of studies on $\mathrm{AI} / \mathrm{ML}$ implementation in asthma, very few studies have reported the application of $\mathrm{AI} / \mathrm{ML}$ systems to the treatment of the disease, as such treatment is usually controlled by specific guidelines. In addition to the two aforementioned studies [45, 46], the effects of anti-inflammatory and antioxidative saffron on the treatment of mild-to-moderate allergic asthma in 80 patients were predicted using a genetic algorithm developed by modifying an artificial neural network system. The accuracy of the prediction system was greater than $99 \%$ in both the training and testing phase [69], which probably makes it suitable for predicting the treatment effect of other asthma drugs. Nevertheless, the performance of this prediction system needs to be confirmed with studies on more patients with allergic or other types of asthma.

\section{Discussion and future directions}

With the continuous improvement of computer learning and the accumulation of asthma-related data, the application of $\mathrm{AI} / \mathrm{ML}$ in asthma has made great progress with good results for specific clinical research purposes [70]. Using $\mathrm{AI} / \mathrm{ML}$ techniques, the mining and analysis of huge clinical, metabolomics, genomics, and other heterogeneous asthma data can help to better understand the pathogenesis and guide individual treatment of the disease. Nevertheless, some AI/ML models developed for asthma diagnosis, classification, assessment, and prediction have many limitations, such as a single data source, small sample, 
or lack of external confirmation, which should be overcome in future studies.

The application of $\mathrm{AI} / \mathrm{ML}$ in asthma is also still limited. For example, although the current studies can be combined with different data or variables to build ML models for identifying asthma phenotypes, the integration of relative comprehensive data or variables, including demographic, environmental, medical history, symptoms, laboratory examination, pulmonary function testing, genomics, metabolomic, and imaging, is still absent. Moreover, $\mathrm{AI} / \mathrm{ML}$ methods have rarely been used to identify or predict patients with severe asthma. Such studies would be of great clinical significance, because an in-depth understanding of asthma phenotypes and the reliable identification of specific subgroups could guide the use of specific drugs, such as biological-targeted agents, to bring precision medicine to asthma patients. In addition, most studies on the application of $\mathrm{AI} / \mathrm{ML}$ in asthma are based on populations and datasets from developed countries, while very little research has been conducted on populations and data in developing countries, where the need for diagnosis, treatment and management is more urgent due to the weaker healthcare systems. To make the situation more challenging, the COVID-19 pandemic has severely disrupted health services for patients with chronic airway diseases. Therefore, the use of $\mathrm{AI} / \mathrm{ML}$ tools to establish a management system for such patients during an infectious disease epidemic should be seriously considered.

\section{AI/ML and COPD}

\section{Application of $A I / M L$ to the screening and diagnosis of COPD}

There are no specific symptoms related to COPD, but the disease can be diagnosed using the pulmonary function test. However, its accuracy is highly dependent on the patient's cooperation, which explains the common under- and overdiagnosis of COPD in clinical practice [71]. To address this challenge, several AI/ML techniques have been used to develop an economical, safe, and effective method for COPD diagnosis. For instance, as an AI diagnostic tool, an "expert system" was built using the following steps: questionnaire formation, WebFlex code development, expert panel pilot validation and clinical validation. The questionnaire information included demography, symptoms, environment, and diagnostic tests. In the clinical validation phase, this "expert system" reached an overall accuracy of $97.5 \%$ in 241 patients [72]. In a similar manner, a subsequent study used data from lung function tests and clinical information from 1,430 subjects to build AI-based software for the diagnosis of COPD [73]. That study showed that the developed software can reach an accuracy of $82 \%$ in 50 COPD patients significantly exceeding the diagnostic performance of pulmonologists $(44.6 \pm 8.7 \%)$. It is therefore clear that AI technology can considerably help clinicians make diagnostic decisions for COPD patients.

To reduce the dependence on lung function tests for early diagnosis of COPD, ML has also been used to mine and analyze transcriptomic data extracted from human bronchial epithelial cells, leading to the identification of abnormal expression of 15 genes in the disease, 10 of which had not previously been reported as COPD biomarkers. The different gene combinations were then analyzed by the random forest algorithm to distinguish non-smokers from smokers and COPD patients [74] (Table 3). Despite the remarkable diagnostic accuracy of each subgroup (65\%), further studies are required to improve the model performance in distinguishing COPD patients from smokers without COPD. Given the lack of specific biomarkers for COPD diagnosis, support vector machine was also integrated with two blood biomarkers, $N$-acetyl-glycoprotein and lipoprotein, which were obtained by comparing 54 COPD patients with 74 normal individuals. The model achieved a diagnostic accuracy of $84.62 \%$ and an AUC of 0.90 [75], suggesting that the combination of ML algorithms with biomarkers may favor COPD diagnosis and reduce the dependence on lung function tests. However, further validation in a larger patient sample is needed.

Respiratory sounds are an important sign of the lungs and their analysis can be useful in the diagnosis of respiratory diseases [76, 77]. In a recent study, 39 features of respiratory sound were integrated with three lung function features derived from 30 COPD patients and 25 healthy subjects, and five ML classifiers were used to categorize normal individuals and COPD patients. Support vector machine and logistic regression achieved a diagnostic accuracy, sensitivity, and specificity of almost $100 \%$ [78]. In a similar approach, 22 different clinical features were extracted from each of 132 subjects. Based on this dataset, a decision support system was developed to diagnose COPD and asthma, with the random forest classifier showing the highest COPD diagnostic accuracy $(97.7 \%)$ compared to other techniques. Moreover, smoking, forced expiratory volume in 1 second (FEV1), age, and forced vital capacity proved to be the main predictors [79]. However, the results of these studies should be carefully interpreted due to their small, single-center samples. 
Table 3. Machine learning studies on chronic obstructive pulmonary disease

\begin{tabular}{|c|c|c|c|c|c|c|c|}
\hline Reference & Category & Study population & $\begin{array}{l}\text { ML } \\
\text { algorithms }\end{array}$ & Input features & Studied outcome & Results & Critical appraisal of the study \\
\hline $\begin{array}{l}\text { Matsumura } \\
\mathrm{K}, 2020[74]\end{array}$ & $\begin{array}{l}\text { Screening and } \\
\text { diagnosis }\end{array}$ & $\begin{array}{l}\text { non-smokers } 68 \\
\text { smokers }=88 \\
\text { COPD subjects }=48\end{array}$ & RF & $\begin{array}{l}\text { Genetic } \\
\text { (transcriptomic data) }\end{array}$ & $\begin{array}{l}\text { Smokers or early } \\
\text { stage of COPD }\end{array}$ & $\begin{array}{l}\text { Each group with } 65 \% \\
\text { accuracy. } \\
\text { The discrimination } \\
\text { accuracy of COPD } \\
\text { subjects from smokers } \\
\text { was only } 29 \%\end{array}$ & $\begin{array}{l}\text { Pros: identification of novel } \\
\text { genes associated with COPD } \\
\text { Cons: limited number of } \\
\text { patients with clear description } \\
\text { of the smoking status }\end{array}$ \\
\hline $\begin{array}{l}\text { Zheng H, } \\
2020[75]\end{array}$ & $\begin{array}{l}\text { Screening and } \\
\text { diagnosis }\end{array}$ & $\begin{array}{l}\text { COPD patients }=54 \\
\text { normal individuals }=74\end{array}$ & SVM & $\begin{array}{l}\text { Serum metabolic } \\
\text { biomarkers }\end{array}$ & $\begin{array}{l}\text { COPD subjects or } \\
\text { not }\end{array}$ & $\begin{array}{l}\text { Accuracy }=84.62 \% \\
\text { AUC }=0.90\end{array}$ & $\begin{array}{l}\text { Pros: based on serum } \\
\text { metabolomics } \\
\text { Cons: should be validated in a } \\
\text { larger clinical sample }\end{array}$ \\
\hline $\begin{array}{l}\text { Haider NS, } \\
2020[78]\end{array}$ & $\begin{array}{l}\text { Screening and } \\
\text { diagnosis }\end{array}$ & $\begin{array}{l}\text { COPD patients }=30 \\
\text { healthy subjects }=25\end{array}$ & $\begin{array}{l}\text { SVM, KNN, } \\
\text { LR, DT, DA }\end{array}$ & $\begin{array}{l}\text { Clinical (lung } \\
\text { sound), spirometry } \\
\text { features }\end{array}$ & $\begin{array}{l}\text { COPD subjects or } \\
\text { not }\end{array}$ & Optimal accuracy $=100 \%$ & $\begin{array}{l}\text { Pros: combination of } \\
\text { spirometry data with lung } \\
\text { sound features for COPD } \\
\text { diagnosis } \\
\text { Cons: small sample and } \\
\text { single-center data }\end{array}$ \\
\hline $\begin{array}{l}\text { Spathis D, } \\
2019 \text { [79] }\end{array}$ & $\begin{array}{l}\text { Screening and } \\
\text { diagnosis }\end{array}$ & 132 patients & $\begin{array}{l}\text { NB, LR, } \\
\text { ANN, SVM, } \\
\text { KNN, DT, RF }\end{array}$ & $\begin{array}{l}\text { Clinical, } \\
\text { demographic }\end{array}$ & Asthma or COPD & $\begin{array}{l}\text { Optimal } \\
\text { accuracy }=97.7 \%\end{array}$ & $\begin{array}{l}\text { Pros: identification of COPD } \\
\text { based on } 22 \text { different clinical } \\
\text { features } \\
\text { Cons: relatively small sample }\end{array}$ \\
\hline $\begin{array}{l}\text { Al Sallakh } \\
\text { MA, } 2018 \\
{[82]}\end{array}$ & $\begin{array}{l}\text { Screening and } \\
\text { diagnosis }\end{array}$ & $\begin{array}{l}\text { Secure Anonymised } \\
\text { Information Linkage } \\
\text { (SAIL) Databank }\end{array}$ & LCA & Clinical (EHR) & $\begin{array}{l}\text { Asthma-COPD } \\
\text { overlap }\end{array}$ & A protocol & $\begin{array}{l}\text { Pros: based on electronic health } \\
\text { records (EHRs) } \\
\text { Cons: incomplete information } \\
\text { of electronic health records }\end{array}$ \\
\hline $\begin{array}{l}\text { Pikoula M, } \\
2019[84]\end{array}$ & $\begin{array}{l}\text { Classification } \\
\text { and } \\
\text { assessment }\end{array}$ & 30,961 COPD patients & $\begin{array}{l}\text { K-means, } \\
\text { hierarchical } \\
\text { clustering }\end{array}$ & Clinical (EHR) & $\begin{array}{l}\text { COPD } \\
\text { phenotypes }\end{array}$ & $\begin{array}{l}\text { Five phenotypes: } \\
\text { anxiety/depression; } \\
\text { non-comorbid; } \\
\text { cardiovascular/diabetes; } \\
\text { severe COPD/frailty; } \\
\text { obesity/atopy }\end{array}$ & $\begin{array}{l}\text { Pros: identification of } \\
\text { phenotypes based on EHRs } \\
\text { Cons: unclear boundaries of } \\
\text { some clusters }\end{array}$ \\
\hline $\begin{array}{l}\text { Burgel PR, } \\
2017 \text { [85] }\end{array}$ & $\begin{array}{l}\text { Classification } \\
\text { and } \\
\text { assessment }\end{array}$ & 6,060 COPD patients & CART & Clinical & $\begin{array}{l}\text { COPD } \\
\text { phenotypes }\end{array}$ & $\begin{array}{l}\text { Five phenotypes: mild } \\
\text { respiratory, } \\
\text { moderate-to-severe } \\
\text { respiratory, } \\
\text { moderate-to-severe } \\
\text { comorbid/obese, very } \\
\text { severe respiratory, very } \\
\text { severe comorbid }\end{array}$ & $\begin{array}{l}\text { Pros: integrated respiratory } \\
\text { characteristics and } \\
\text { comorbidities } \\
\text { Cons: assessment of } \\
\text { comorbidities was based on } \\
\text { physician diagnoses that did } \\
\text { not consider occult conditions }\end{array}$ \\
\hline $\begin{array}{l}\text { Yoon HY, } \\
2019[86]\end{array}$ & $\begin{array}{l}\text { Classification } \\
\text { and } \\
\text { assessment }\end{array}$ & 1,195 COPD patients & K-means & $\begin{array}{l}\text { Clinical (seven } \\
\text { variables) }\end{array}$ & $\begin{array}{l}\text { COPD } \\
\text { phenotypes }\end{array}$ & $\begin{array}{l}\text { Four phenotypes: } \\
\text { putative asthma-COPD } \\
\text { overlap, mild COPD, } \\
\text { moderate COPD, severe } \\
\text { COPD }\end{array}$ & $\begin{array}{l}\text { Pros: demonstrated that } \\
\text { phenotype is linked to the } \\
\text { occurrence of acute } \\
\text { exacerbation } \\
\text { Cons: short follow-up duration }\end{array}$ \\
\hline $\begin{array}{l}\text { Kim WJ, } \\
2018[87]\end{array}$ & $\begin{array}{l}\text { Classification } \\
\text { and } \\
\text { assessment }\end{array}$ & $\begin{array}{l}\text { 1,676 COPD patients } \\
\text { from } 13 \text { Asian cities }\end{array}$ & $\begin{array}{l}\text { Hierarchical } \\
\text { cluster } \\
\text { analysis }\end{array}$ & Clinical & $\begin{array}{l}\text { COPD } \\
\text { phenotypes }\end{array}$ & $\begin{array}{l}\text { Three phenotypes: worse } \\
\text { lung function and fewer } \\
\text { symptoms, worse lung } \\
\text { function and more } \\
\text { symptoms. milder COPD } \\
\text { and a preserved FEV1 } \\
\text { and FEV1/FVC ratio }\end{array}$ & $\begin{array}{l}\text { Pros: identification of COPD } \\
\text { subgroups in a large Asian } \\
\text { sample } \\
\text { Cons: } 90 \% \text { male subjects }\end{array}$ \\
\hline $\begin{array}{l}\text { Castaldi PJ, } \\
2014 \text { [88] }\end{array}$ & $\begin{array}{l}\text { Classification } \\
\text { and } \\
\text { assessment }\end{array}$ & 10,192 smokers & K-means & Clinical & $\begin{array}{l}\text { COPD } \\
\text { phenotypes }\end{array}$ & $\begin{array}{l}\text { Four phenotypes: } \\
\text { relatively resistant } \\
\text { smokers, mild upper } \\
\text { zone emphysema- } \\
\text { predominant, airway } \\
\text { disease-predominant, } \\
\text { severe emphysema }\end{array}$ & $\begin{array}{l}\text { Pros: identification of } \\
\text { phenotypes based on airway } \\
\text { disease and emphysema } \\
\text { Cons: non-inclusion of } \\
\text { biomarkers and comorbidities }\end{array}$ \\
\hline $\begin{array}{l}\text { Bodduluri S, } \\
2020[90]\end{array}$ & $\begin{array}{l}\text { Classification } \\
\text { and } \\
\text { assessment }\end{array}$ & 8980 individuals & DNN, RF & Spirometry data & $\begin{array}{l}\text { Chest CT } \\
\text { phenotypes } \\
\text { (normal, airway } \\
\text { predominant, } \\
\text { emphysema } \\
\text { predominant, and } \\
\text { mixed } \\
\text { emphysema/ } \\
\text { airway) }\end{array}$ & $\begin{array}{l}\text { The DNN model had the } \\
\text { highest accuracy (AUC = } \\
0.80 \text { and } 0.91 \text { ) }\end{array}$ & $\begin{array}{l}\text { Pros: used spirometry data to } \\
\text { train the model } \\
\text { Cons: nonsmokers with and at } \\
\text { risk for COPD were not } \\
\text { included in the cohort }\end{array}$ \\
\hline $\begin{array}{l}\text { Gawlitza J, } \\
2019[94]\end{array}$ & $\begin{array}{l}\text { Classification } \\
\text { and } \\
\text { assessment }\end{array}$ & 75 COPD patients & $\begin{array}{l}\text { KNN, } \\
\text { XGBoost, } \\
\text { ANN }\end{array}$ & $\begin{array}{l}\text { Quantified } \\
\text { computed } \\
\text { tomography }\end{array}$ & $\begin{array}{l}\text { Pulmonary } \\
\text { function }\end{array}$ & $\begin{array}{l}\text { KNN model with the } \\
\text { lowest mean relative } \\
\text { error }(16 \%)\end{array}$ & $\begin{array}{l}\text { Pros: prediction of lung } \\
\text { function values from } \\
\text { quantitative computed } \\
\text { tomography parameters } \\
\text { Cons: small sample }\end{array}$ \\
\hline $\begin{array}{l}\text { Westcott A, } \\
2019[95]\end{array}$ & $\begin{array}{l}\text { Classification } \\
\text { and } \\
\text { assessment }\end{array}$ & 95 COPD patients & LR, SVM & $\begin{array}{l}\text { Thoracic computed } \\
\text { tomography }\end{array}$ & Lung ventilation & $\begin{array}{l}\text { Accuracy }=88 \%, \\
\text { AUC }=0.82\end{array}$ & $\begin{array}{l}\text { Pros: development of a } \\
\text { computed tomography } \\
\text { analysis pipeline } \\
\text { Cons: few mild COPD patients }\end{array}$ \\
\hline $\begin{array}{l}\text { González G, } \\
2018 \text { [96] }\end{array}$ & $\begin{array}{l}\text { Classification } \\
\text { and }\end{array}$ & $\begin{array}{l}8,983 \text { COPDGene } \\
\text { participants and } 1,672\end{array}$ & $\begin{array}{l}\text { Convolution } \\
\text { al neural }\end{array}$ & $\begin{array}{l}\text { Chest computed } \\
\text { tomography }\end{array}$ & $\begin{array}{l}\text { COPD, stage, } \\
\text { acute respiratory }\end{array}$ & $\begin{array}{l}\text { C-index }=0.856 \text {, accuracy } \\
=51.1 \% \text { in COPDGene }\end{array}$ & $\begin{array}{l}\text { Pros: based on chest computed } \\
\text { tomography images }\end{array}$ \\
\hline
\end{tabular}




\begin{tabular}{|c|c|c|c|c|c|c|c|}
\hline Reference & Category & Study population & $\begin{array}{l}\text { ML } \\
\text { algorithms }\end{array}$ & Input features & Studied outcome & Results & Critical appraisal of the study \\
\hline & assessment & ECLIPSE participants & network & & $\begin{array}{l}\text { disease events, } \\
\text { mortality }\end{array}$ & cohort & $\begin{array}{l}\text { Cons: high training } \\
\text { computational cost and } \\
\text { memory requirements }\end{array}$ \\
\hline $\begin{array}{l}\text { Peng J, } \\
2020 \text { [97] }\end{array}$ & $\begin{array}{l}\text { Classification } \\
\text { and } \\
\text { assessment }\end{array}$ & $\begin{array}{l}410 \text { hospitalized } \\
\text { AECOPD patients }\end{array}$ & DT & $\begin{array}{l}\text { Clinical (medical } \\
\text { records) }\end{array}$ & $\begin{array}{l}\text { Mild and severe } \\
\text { AECOPD }\end{array}$ & Accuracy $=80.3 \%$ & $\begin{array}{l}\text { Pros: fast identification of the } \\
\text { deterioration and death risk of } \\
\text { AECOPD patients } \\
\text { Cons: non-inclusion of } \\
\text { interleukin and other } \\
\text { inflammatory cytokines }\end{array}$ \\
\hline $\begin{array}{l}\text { Goto T, } \\
2019[98]\end{array}$ & $\begin{array}{l}\text { Management } \\
\text { and } \\
\text { monitoring }\end{array}$ & $\begin{array}{l}44,929 \text { hospitalized } \\
\text { COPD patients }\end{array}$ & $\begin{array}{l}\text { Lasso } \\
\text { regression, } \\
\text { DNN }\end{array}$ & Clinical & $\begin{array}{l}\text { 30-day } \\
\text { readmission }\end{array}$ & C-statistic $=0.61$ & $\begin{array}{l}\text { Pros: huge sample size and } \\
\text { more than } 1000 \text { predictors } \\
\text { Cons: unable to identify } \\
\text { patients readmitted to different } \\
\text { hospitals }\end{array}$ \\
\hline $\begin{array}{l}\text { Min X, } \\
2019[99]\end{array}$ & $\begin{array}{l}\text { Management } \\
\text { and } \\
\text { monitoring }\end{array}$ & $\begin{array}{l}111,992 \text { patients from the } \\
\text { Geisinger Health System }\end{array}$ & $\begin{array}{l}\text { LR, RF, SVM, } \\
\text { GBDT, MLP }\end{array}$ & Medical claims data & $\begin{array}{l}\text { 30-day } \\
\text { readmission }\end{array}$ & Optimal AUC $=0.653$ & $\begin{array}{l}\text { Pros: combined knowledge } \\
\text { and data driven features } \\
\text { Cons: lack of mortality } \\
\text { information for patients }\end{array}$ \\
\hline $\begin{array}{l}\text { Cavailles A, } \\
2020[100]\end{array}$ & $\begin{array}{l}\text { Management } \\
\text { and } \\
\text { monitoring }\end{array}$ & $\begin{array}{l}\text { 143,006 patients } \\
\text { hospitalized for AECOPD }\end{array}$ & DT & Clinical & $\begin{array}{l}\text { Risk of } \\
\text { readmission }\end{array}$ & $\begin{array}{l}\text { Previous admission } \\
\text { times was the most } \\
\text { important risk of } \\
\text { readmission }\end{array}$ & $\begin{array}{l}\text { Pros: identification of variables } \\
\text { associated with readmission } \\
\text { Cons: no information on } \\
\text { spirometry or severity }\end{array}$ \\
\hline $\begin{array}{l}\text { Chen W, } \\
2020 \text { [101] }\end{array}$ & $\begin{array}{l}\text { Management } \\
\text { and } \\
\text { monitoring }\end{array}$ & 4,167 subjects & $\mathrm{RF}$ & Clinical, spirometry & $\begin{array}{l}\text { Prebronchodilator } \\
\text { FEV1, risk of } \\
\text { airflow limitation }\end{array}$ & C-statistic $=0.86-0.87$ & $\begin{array}{l}\text { Pros: development of a } \\
\text { personalized risk model to } \\
\text { predict the risk of airflow } \\
\text { limitation } \\
\text { Cons: lack of ethnic diversity in } \\
\text { the cohort }\end{array}$ \\
\hline $\begin{array}{l}\text { Ma X, } \\
2020[102]\end{array}$ & $\begin{array}{l}\text { Management } \\
\text { and } \\
\text { monitoring }\end{array}$ & $\begin{array}{l}\text { COPD patients }=441 \\
\text { control subjects }=192\end{array}$ & $\begin{array}{l}\text { KNN, LR, } \\
\text { DT, SVM, } \\
\text { ANN, } \\
\text { XGBoost }\end{array}$ & Genetic, clinical & Early-stage COPD & $\begin{array}{l}\text { KNN and LR had the } \\
\text { highest precision }(82 \%) \\
\text { and accuracy }(81 \%) \\
\text { ANN had the highest } \\
\text { sensitivity }(100 \%)\end{array}$ & $\begin{array}{l}\text { Pros: identification of the } \\
\text { association of genes and COPD } \\
\text { development } \\
\text { Cons: unbalanced samples } \\
\text { from the seven centers; only } \\
\text { nine } 9 \text { genes and five clinical } \\
\text { features were obtained }\end{array}$ \\
\hline $\begin{array}{l}\text { Lanclus M, } \\
2019[103]\end{array}$ & $\begin{array}{l}\text { Management } \\
\text { and } \\
\text { monitoring }\end{array}$ & 62 COPD patients & SVM & $\begin{array}{l}\text { Functional } \\
\text { respiratory imaging }\end{array}$ & $\begin{array}{l}\text { COPD } \\
\text { exacerbations }\end{array}$ & $\begin{array}{l}\text { Accuracy }=80.65 \%, \\
\text { positive predictive } \\
\text { value }=82.35 \%\end{array}$ & $\begin{array}{l}\text { Pros: use of functional } \\
\text { respiratory imaging for } \\
\text { AECOPD prediction } \\
\text { Cons: more advanced COPD } \\
\text { patients in the cohort }\end{array}$ \\
\hline $\begin{array}{l}\text { Wang C, } \\
2020[104]\end{array}$ & $\begin{array}{l}\text { Management } \\
\text { and } \\
\text { monitoring }\end{array}$ & $\begin{array}{l}\text { AECOPD patients }=135 \\
\text { not } \mathrm{AECOPD} \text { patients }= \\
168\end{array}$ & $\begin{array}{l}\text { RF, SVM, LR, } \\
\text { KNN, NB }\end{array}$ & Clinical (EMRs) & $\begin{array}{l}\text { COPD acute } \\
\text { exacerbations }\end{array}$ & $\begin{array}{l}\text { Optimal } \\
\text { sensitivity }=80 \%, \\
\text { specificity }=83 \%, \\
\text { positive predictive } \\
\text { value }=81 \%, \text { negative } \\
\text { predictive value }=85 \%, \\
\text { and AUC }=0.90 \text { from } \\
\text { SVM }\end{array}$ & $\begin{array}{l}\text { Pros: decision support for } \\
\text { clinicians } \\
\text { Cons: single-center cohort }\end{array}$ \\
\hline $\begin{array}{l}\text { Luo L, } \\
2020[107]\end{array}$ & $\begin{array}{l}\text { Management } \\
\text { and } \\
\text { monitoring }\end{array}$ & $\begin{array}{l}780,295 \text { hospitalizations } \\
\text { data }\end{array}$ & $\begin{array}{l}\text { LR, RF, } \\
\text { XGBoost }\end{array}$ & $\begin{array}{l}\text { Medical insurance } \\
\text { data }\end{array}$ & $\begin{array}{l}\text { High-cost COPD } \\
\text { patients }\end{array}$ & $\begin{array}{l}\text { AUC }=0.787(\mathrm{LR}) ; \\
\text { AUC }=0.792(\mathrm{RF}) ; \\
\text { AUC }=0.801(\text { XGBoost })\end{array}$ & $\begin{array}{l}\text { Pros: identification of high } \\
\text { costs for COPD patients } \\
\text { Cons: no smoking status, } \\
\text { household income, or family } \\
\text { population information }\end{array}$ \\
\hline $\begin{array}{l}\text { Morales DR, } \\
2018 \text { [108] }\end{array}$ & $\begin{array}{l}\text { Management } \\
\text { and } \\
\text { monitoring }\end{array}$ & 54879 COPD patients & LR, SVM & Clinical & 1-year mortality & C-statistic $=0.723$ & $\begin{array}{l}\text { Pros: use of external data to } \\
\text { validate models } \\
\text { Cons: analysis of patients only } \\
\text { with complete data }\end{array}$ \\
\hline $\begin{array}{l}\text { Moll M, } \\
2020[109]\end{array}$ & $\begin{array}{l}\text { Management } \\
\text { and } \\
\text { monitoring }\end{array}$ & $\begin{array}{l}\text { 2,632 participants from } \\
\text { COPDGene cohort and } \\
\text { 1,268 participants from } \\
\text { ECLIPSE cohort }\end{array}$ & RF & $\begin{array}{l}\text { Clinical, spirometry, } \\
\text { imaging }\end{array}$ & $\begin{array}{l}\text { Time to death } \\
\text { from any cause }\end{array}$ & $\begin{array}{l}\text { C-index } \geq 0.7 \text { in both } \\
\text { cohorts }\end{array}$ & $\begin{array}{l}\text { Pros: prediction of all-cause } \\
\text { mortality } \\
\text { Cons: cohorts were not } \\
\text { representative of the general } \\
\text { population }\end{array}$ \\
\hline $\begin{array}{l}\text { Orchard P, } \\
2018[110]\end{array}$ & Treatment & 135 COPD patients & $\begin{array}{l}\text { Sparse } \\
\text { maximum- } \\
\text { margin } \\
\text { classifier, } \\
\text { ensembles of } \\
\text { boosted } \\
\text { classifier, } \\
\text { multitask } \\
\text { neural } \\
\text { network } \\
\text { model }\end{array}$ & $\begin{array}{l}\text { Clinical } \\
\text { (telemonitoring } \\
\text { data), weather }\end{array}$ & $\begin{array}{l}\text { Admission and } \\
\text { initiation of oral } \\
\text { corticosteroid } \\
\text { treatment }\end{array}$ & Optimal AUC $=0.74$ & $\begin{array}{l}\text { Pros: the model serves as a } \\
\text { guide for corticosteroid } \\
\text { therapy } \\
\text { Cons: lack of a gold standard } \\
\text { definition for exacerbation }\end{array}$ \\
\hline
\end{tabular}

Abbreviations: ANN, artificial neural networks; AUC, the area under the curve; BN, bayesian networks; CART, classification and regression tree; DA, discriminant analysis; DNN, deep neural network; DT, decision trees; EMRs, electronic medical records; EHR, electronic health records; GBDT, gradient boosting decision tree; KNN, k-nearest neighbors; LCA, latent class analysis; LR, logistic regression; MLP, multi-layer perceptron; NB, naïve Bayes; RF-random forest; SVM-support vector machine.

Inequities in access to medical resources also affect the diagnosis of COPD, especially in less developed areas. Therefore, an automated telehealth AI system was recently developed and verified in 780 
patients from several medical institutions [80]. The diagnostic accuracy reached $97 \%$, and the simple equipment involved may allow its use in remote areas and in patients with less mobility.

Some patients may also have both asthma and COPD, known as asthma-COPD overlap (ACO). However, the lack of accurate diagnostic criteria has led to insufficient data on the prevalence and treatment of ACO [81]. The only relevant study of which we are aware has been registered so far as a protocol, and it aims to precisely classify COPD, asthma, and ACO patients by applying a modified latent class model to EHRs from the Secure Anonymized Information Linkage databank [82]. The analyzed data will include demographic characteristics, history of present illness, allergy, and smoking history, so the future study is expected to provide useful information.

\section{Application of AI/ML to the classification and assessment of COPD}

According to the Global Obstructive Lung Disease Initiative, COPD patients are classified into four phenotypes based on their symptomatic assessment, exacerbation and hospitalization history [83]. However, the discriminatory ability of this method is insufficient, leading to the AI/ML-based integration of additional information, including physiological features, lung function test results, comorbidities, genome, and biomarkers, for precise phenotype classification, severity assessment, and therapeutic guidance [84-89]. For example, k-means clustering was applied to analyze eight factors in 1,195 COPD patients such as physiological features, medical history, COPD assessment test score, and post-bronchodilator FEV1. Four phenotypes were identified: putative asthma-COPD overlap (cluster 1), mild COPD (cluster 2), moderate COPD (cluster 3), and severe COPD (cluster 4). Cluster 4 showed the worst post-bronchodilator FEV1 (46.7\%), the shortest 6-min walking distance $(365 \mathrm{~m})$, and the highest COPD assessment test score (17.5), whereas cluster 1 showed the highest risk of acute exacerbation [86]. Nevertheless, the results need to be supported by a longer follow-up duration ( $>6$ months). In another study, the variation in lung function and life quality scores among 1,676 Asian COPD patients were monitored for one year, identifying three phenotypes of COPD patients. Cluster 1 was defined by worse lung function but fewer symptoms, while cluster 3 showed mild severity but higher body mass index; cluster 2 showed severe disease and more symptoms, including the highest risk of acute exacerbation and rate of FEV1 deterioration [87]. However, one of the main study limitations was the high proportion of male subjects (90\%). Moreover, using two ML methods (k-means and hierarchical clustering) and based on comorbidities and risk factors, 30,961 COPD patients were classified into five phenotypes: anxiety and depression, severe airflow limitation and weakness, cardiovascular disease and diabetes, as well as obesity/atopy and non-comorbidity [84]. Although the aforementioned studies used different ML algorithms and clinical variables and had some limitations, all supported the idea that exploring different phenotypic classification can improve individualized treatment. For similar purpose, the spirometry data of 8980 individuals (COPDGene cohort study) was used to develop a deep neural network model for the identification of four chest computed tomography imaging phenotypes (normal, airway predominant, emphysema predominant, and mixed emphysema/airway). The deep neural network model had a higher accuracy both in the classification of predominant emphysema/airway phenotypes (AUC $=0.80)$ and predominant emphysema/small airway phenotypes $(\mathrm{AUC}=0.91)$ than FEV1/forced vital capacity, FEV1\% predicted and random forest classifier. However, non-smokers with and at risk for COPD should be included in future studies [90].

The assessment of persistent airflow limitation in COPD patients depends on lung function tests. However, only some COPD patients complete these tests in clinical practice, limiting the diagnosis of airway limitation to $56 \%[91,92]$. Considering that it is difficult to identify FEV1 values in structured EHRs, an automatic AI tool was designed to mine FEV1 values in EHRs of 41,689 veterans with COPD. The novel AI tool showed an accuracy of $95 \%$, serving as a helpful tool for the assessment of COPD severity in large patient population [93].

Chest computed tomography has also been widely used to detect lung texture abnormalities and assess the state of COPD. However, a large amount of image data cannot be identified with the naked eye, highlighting the need for AI/ML systems in this field [94]. In a recent prospective study, the pulmonary ventilation function of COPD was assessed using a support vector machine and logistic regression algorithms to analyze chest computed tomography images. The assessment model (quadratic support vector machine) was based on 87 image features, and its validity was tested in 27 COPD patients with an accuracy of $88 \%$ and an AUC value of 0.82 [95]. While these results are encouraging, the sample was small and most patients had moderate to severe COPD, suggesting that condign mild COPD patients should be included in future works. In another study, a convolutional neural network algorithm was used to 
analyze chest computed tomography images from smokers and to assess the diagnosis, stage, exacerbation, and mortality of COPD patients. Smokers in the study were divided into a training phase consisting of 8,983 participants and an evaluation phase consisting of 1,672 participants, which came from COPDGene and ECLIPSE cohorts. The algorithm yielded a c-index of 0.856 for COPD detection and an accuracy of $51.1 \%$ for the exact determination of the COPD stage in the COPDGene cohort. Moreover, the c-indices for predicting exacerbation and mortality were 0.64 and 0.72 in the COPDGene cohort, and 0.55 and 0.60 in the ECLIPSE cohort [96]. These results indicated better performance of the convolutional neural network in the COPDGene cohort, while suggesting its applicability in stage classification and risk assessment of COPD at the population level. However, this method may have limited applicability because it requires extensive training and computational resources.

Assessing the severity of hospitalized acute exacerbations of COPD (AECOPD) patients is also beneficial to clinical practice. Hence, a modified decision tree algorithm was used to analyze 28 clinical features, including demographics, medical history, and biomarkers derived from 202 inpatients with severe AECOPD and 208 inpatients with mild AECOPD. The classification of severe and mild patients was based on their admission to the intensive care unit. The overall accuracy of the developed classifier reached $80.3 \%$, suggesting that it can be used to assess the severity of hospitalized AECOPD patients [97]; however, the patient's body mass index and other inflammatory cytokines should be included in a future prospective study.

\section{Application of Al/ML to the management and monitoring of COPD}

Persistent chronic airway inflammation and airflow limitation in COPD can induce the recurrence of acute exacerbation and readmission. In order to effectively manage COPD patients and monitor the disease, several studies have used ML-based approaches, which proved to be more effective than conventional methods [98-100]. In particular, ML algorithms, such as lasso regression and deep neural network, were used to analyze 44,929 COPD hospitalizations divided into a training $(70 \%)$ and a test $(30 \%)$ set. The developed models aimed to predict readmission within 30 days after discharge and showed higher prediction ability $($ c-statistic $=0.61)$ than the traditional method [98]. Similarly, several non-deep and deep ML algorithms were used to mine a database containing medical claims data of COPD patients in order to predict readmission 30 days after discharge, and the optimal AUC was 0.653 [99]. A retrospective study in France applied decision tree analysis to predict the readmission of 143,006 COPD patients older than 40 years. The study not only showed that the most relevant risk factor of readmission was the number of previous admissions, but it also assessed the cost of readmission within six months [100]. Although these studies have reported several limitations, such as the lack of important clinical features, the prediction models could be used by clinicians as a reference.

Persistent airflow limitation along with persistent respiratory symptoms make COPD a lifelong and life-threatening disease. Thus, it is particularly important to monitor variation in lung function and prevent persistent airflow limitation. A ML model based on random forest was recently developed using spirometry data obtained from 4,167 participants in order to predict individuals most likely to develop or have COPD. The primary outcome of the model was FEV1, while the secondary outcome was the risk of airflow limitation (FEV1/forced vital capacity). This model may be a useful tool for personalized risk prediction of airflow limitation and early prevention of COPD [101].

Given the irreversibility of COPD, its early detection and diagnosis are crucial. Thus, six ML models were used to predict the development of COPD based on 101 single-nucleotide polymorphisms and 5 clinical characteristics of 441 patients and 192 normal participants. Among them, 9 single-nucleotide polymorphisms were significantly associated with this disease, including 6 risk and 3 protective factors. In the test set, among the examined models, the k-nearest neighbor classifier and logistic regression showed the highest precision of $82 \%$ and accuracy of $81 \%$, while the highest sensitivity (recall) of $100 \%$ was achieved using the multilayer perceptron classifier based on the artificial neural network algorithm [102]. Although only a few genes and clinical features were included, this model may be effective for early diagnosis of COPD, compensating for the lack of lung function testing among patients in the early disease stages.

ML algorithms were also used to analyze functional respiratory imaging for the prediction of exacerbation and early identification of AECOPD patients [103]. Similarly, a series of ML algorithms (logistic regression, random forest, naïve Bayesian, support vector machine and k-nearest neighbor) were used to mine EHRs data derived from 135 AECOPD and 168 control subjects. Further validation and comparison of the developed models indicated that the support vector machine algorithm showed the 
best performance (AUC $=0.90)$ [104]. Consequently, ML models, and especially the support vector machine model, can help physicians identify AECOPD patients and make timely decisions; however, the models' performance should be further validated using data from external sources. In another approach, a mobile telehealth system was designed to improve self-management in COPD and detect acute exacerbations of stable COPD patients in a timely manner. The system could continuously monitor the clinical information of the enrolled patients at home and warn of an acute exacerbation three days in advance [105]. Although the accuracy was only $40 \%$ and the study lasted only six months, the development of a simple, effective AI-based monitoring and warning system deserves further investigation.

The global economic burden of COPD increases every year, a trend exacerbated by the aging population. In Europe, the total cost of COPD is estimated at $56 \%$ of annual healthcare expenditure for respiratory diseases [106]. To identify and predict the costs of COPD patients in China and to provide crucial health management information, three ML algorithms (logistic regression, random forest, and extreme gradient boosting) were used to analyze 54 different demographic parameters and medical information from 780,295 hospitalizations. Although all ML models showed excellent predictive efficiency, the extreme gradient boosting model showed the highest sensitivity (71.3\%) and AUC (0.801) [107], indicating that it may serve as a valuable predictive tool for patients, clinicians, insurance policy makers, and other healthcare professionals in developing countries.

Since COPD is one leading causes of death worldwide, some studies have also used $\mathrm{AI} / \mathrm{ML}$ technology to predict the risk of mortality in patients with COPD [108, 109]. For instance, a total of 30 clinical, lung function, and chest imaging features obtained from 3,900 participants with moderate to severe COPD were analyzed to build a random forest model for mortality prediction. The novel model showed good prediction performance (C-index $>0.7$ ), and the optimal risk predictors were the 6 -min walk test, the FEV1 value, and the pulmonary artery-to-aorta ratio [109]. Hence, the novel ML model can be a useful tool to guide the early intervention of COPD to avoid further deterioration, but more external population cohorts are needed for validation.

\section{Application of AI/ML in COPD treatment}

$\mathrm{AI} / \mathrm{ML}$ technologies can monitor, integrate, and analyze large-scale, heterogeneous clinical information from COPD patients; suggest optimal individualized treatments; and reduce over- or undertreatment caused by clinician errors. However, similar to asthma, we found only one study related to the application of $\mathrm{AI} / \mathrm{ML}$ in COPD treatment. In that work, several ML models (e.g. sparse maximum-margin classifier, ensembles of boosted classifier, multitask neural network model) were developed based on 153 predictive factors derived from telemonitoring of physiological, symptom, and baseline data from 135 patients with moderate to severe COPD. The data included demography, severity, quality of life and hospital admissions, and the goal was to detect acute exacerbations and guide the corticosteroid therapy of COPD. Irrespective of acute exacerbations or corticosteroid use, the optimal ML model (multitask neural network) showed better AUC values than non-ML methods $(0.74-0.77$ vs $0.60-0.66)$, and its performance was not improved by adding weather data [110]. However, the evaluation of model performance relied on cross-validation rather than multiple independent cohorts, suggesting the need for further study.

\section{Discussion and future directions}

Given the structured data from pulmonary function testing and their important role in the diagnosis and management of COPD, AI/ML techniques were combined with such testing early in the field in order to help clinicians assess lung function [111]. Other studies have focused on the use of $\mathrm{AI} / \mathrm{ML}$ methods to reduce the reliance on pulmonary function testing in clinical practice. Our literature review also showed that ML methods have been increasingly used in recent years for the identification of COPD phenotypes and for the prediction of acute exacerbation and death risk. However, similar to the limitations of $\mathrm{AI} / \mathrm{ML}$ techniques in asthma, such as single-source populations and lack of external validation, the model still needs to be validated in more prospective studies using a large real-world dataset as well as clinical data from continuous monitoring.

Although there have been significant advances in understanding and managing COPD using $\mathrm{AI} / \mathrm{ML}$ methods, there are still many unmet needs. For example, airflow limitation is the hallmark of COPD, and studies have found that even in patients with similar FEV1 levels, there are significant differences in the degree of respiratory symptoms, frequency of acute exacerbations, and activity endurance [112]. The underlying biological mechanism remains unknown, indicating the importance of phenotypic studies in COPD patients. The current four phenotypes of COPD proposed by the Global Obstructive Lung Disease Initiative are insufficient for individualized 
therapy; thus, the development of phenotype-specific therapeutic strategies should be extensively studied in the future [85]. We expect that the integration and analysis of different data using AI/ML technologies may provide new insights into the COPD phenotype.

$\mathrm{AI} / \mathrm{ML}$ may also play a significant role in the treatment and management of patients with stable chronic airway diseases. Inhalation therapy is the basic therapeutic approach for stable COPD. However, stable COPD patients may misuse inhaled devices due to the diversity of inhaled drugs and devices and the lack of medical assistance. Therefore, the application of $\mathrm{AI} / \mathrm{ML}$ methods for the early detection of errors and the improvement of patient compliance should be further investigated. AI/ML studies are also worth conducting in low-income individuals or regions, as they usually exhibit high morbidity and experience a heavy financial burden due to COPD; in addition, the relatively delayed generation of clinical data in their health systems leads to poor data integrity.

\section{Conclusions}

In recent years, the application of $\mathrm{AI} / \mathrm{ML}$ techniques in the medical field has evolved rapidly, while several $\mathrm{AI} / \mathrm{ML}$ tools have been extensively studied and applied to chronic airway diseases. This review summarizes the recent advances in the implementation of $\mathrm{AI} / \mathrm{ML}$ techniques in the screening and diagnosis, classification and assessment, management and monitoring, as well as treatment of asthma and COPD. Our research supports that $\mathrm{AI} / \mathrm{ML}$ techniques can be used effectively to analyze and integrate large, heterogeneous medical data, thus assisting physicians in making decisions and guiding clinical practice. In addition, these techniques can be applied to analyze different responses to treatment, providing therapeutic guidance for specific phenotypes required in precision medicine, and establish a management system for chronic airway disease patients during an infectious disease epidemic. However, the results about AI/ML tools should be interpreted and generalized with caution. The AI/ML techniques cannot yet replace clinicians in the diagnosis and treatment of chronic airway diseases, and further studies are needed to examine the effect of several parameters on ML model construction and to verify existing findings with larger samples and external data sources.

\section{Abbreviations}

ACO: asthma-COPD overlap; AECOPD: acute exacerbations of COPD; AI: artificial intelligence; ML: machine learning; AUC: area under the receiver operating characteristic curve; COPD: chronic obstructive pulmonary disease; ECLIPSE Study: "Evaluations of COPD longitudinally to identify predictive surrogate endpoints"; EHRs: electronic health records; FEV1: forced expiratory volume in 1 second.

\section{Acknowledgements}

This work was supported by grants from the Sichuan Science and Technology Project (2017SZ0068) to Hui Mao and from the Deyang Science and Technology Project (2018SZS056) to Yinhe Feng.

\section{Competing Interests}

The authors have declared that no competing interest exists.

\section{References}

1. Esteva A, Robicquet A, Ramsundar B, et al. A guide to deep learning in healthcare. Nat Med. 2019; 25(1): 24-29.

2. Rajkomar A, Dean J, Kohane I. Machine Learning in Medicine. N Engl J Med. 2019; 380(14): 1347-1358

3. Erickson BJ, Korfiatis P, Akkus Z, Kline TL. Machine Learning for Medical Imaging. Radiographics. 2017; 37(2): 505-515.

4. McBee MP, Awan OA, Colucci AT, et al. Deep Learning in Radiology. Acad Radiol. 2018; 25(11): 1472-1480.

5. Ho D, Schierding W, Wake M, Saffery R, O\&\#39, Sullivan J. Machine Learning SNP Based Prediction for Precision Medicine. Front Genet. 2019; 10: 267.

6. van IJzendoorn D, Szuhai K, Briaire-de Bruijn IH, Kostine M, Kuijjer ML, Bovée J. Machine learning analysis of gene expression data reveals novel diagnostic and prognostic biomarkers and identifies therapeutic targets for soft tissue sarcomas. PLoS Comput Biol. 2019; 15(2): e1006826.

7. Feng Y, Teh HS, Cai Y. Deep Learning for Chest Radiology: A Review. Curr Radiol Rep. 2019; 7(8): 24.

8. Angelini E, Dahan S, Shah A. Unravelling machine learning: insights in respiratory medicine. Eur Respir J. 2019; 54(6): 1901216.

9. Shen Y, Huang S, Kang J, et al. Management of airway mucus hypersecretion in chronic airway inflammatory disease: Chinese expert consensus (English edition). Int J Chron Obstruct Pulmon Dis. 2018; 13: 399-407.

10. Tan KS, Lim RL, Liu J, et al. Respiratory Viral Infections in Exacerbation of Chronic Airway Inflammatory Diseases: Novel Mechanisms and Insights From the Upper Airway Epithelium. Front Cell Dev Biol. 2020; 8: 99.

11. Bao Z, Xiong J, Li W, Chen Z, Shen H, Ying S. Genomic instability in chronic airway inflammatory diseases. 2015; 38(2): 117-124.

12. Barnes PJ. Cellular and molecular mechanisms of asthma and COPD. Clin Sci (Lond). 2017; 131(13): 1541-1558.

13. Exarchos KP, Beltsiou M, Votti CA, Kostikas K. Artificial intelligence techniques in asthma: a systematic review and critical appraisal of the existing literature. Eur Respir J. 2020; 56(3): 2000521.

14. Buch VH, Ahmed I, Maruthappu M. Artificial intelligence in medicine: current trends and future possibilities. Br J Gen Pract. 2018; 68(668): 143-144.

15. Mekov E, Miravitlles M, Petkov R. Artificial intelligence and machine learning in respiratory medicine. Expert Rev Respir Med. 2020; 14(6): 559-564.

16. Sharafoddini A, Dubin JA, Lee J. Patient Similarity in Prediction Models Based on Health Data: A Scoping Review. JMIR Med Inform. 2017; 5(1): e7.

17. Bi Q, Goodman KE, Kaminsky J, Lessler J. What is Machine Learning? A Primer for the Epidemiologist. Am J Epidemiol. 2019; 188(12): 2222-2239.

18. Artificial intelligence and medical imaging 2018: French Radiology Community white paper. Diagn Interv Imaging. 2018; 99(11): 727-742.

19. Collins GS, Reitsma JB, Altman DG, Moons KG. Transparent reporting of a multivariable prediction model for individual prognosis or diagnosis (TRIPOD): the TRIPOD statement. BMJ. 2015; 350: g7594.

20. Lillywhite A, Wolbring G. Coverage of ethics within the artificial intelligence and machine learning academic literature: The case of disabled people. Assist Technol. 2019: 1-7.

21. Aaron SD, Boulet LP, Reddel HK, Gershon AS. Underdiagnosis and Overdiagnosis of Asthma. Am J Respir Crit Care Med. 2018; 198(8): 1012-1020.

22. Aaron SD, Vandemheen KL, FitzGerald JM, et al. Reevaluation of Diagnosis in Adults with Physician-Diagnosed Asthma. JAMA. 2017; 317(3): 269-279.

23. Wi CI, Sohn S, Rolfes MC, et al. Application of a Natural Language Processing Algorithm to Asthma Ascertainment. An Automated Chart Review. Am J Respir Crit Care Med. 2017; 196(4): 430-437.

24. Wi CI, Sohn S, Ali M, et al. Natural Language Processing for Asthma Ascertainment in Different Practice Settings. J Allergy Clin Immunol Pract. 2018; 6(1): 126-131. 
25. Kaur $\mathrm{H}$, Sohn $\mathrm{S}$, Wi CI, et al. Automated chart review utilizing natural language processing algorithm for asthma predictive index. BMC Pulm Med. 2018; 18(1): 34

26. Alizadeh B, Safdari R, Zolnoori $\mathrm{M}$, Bashiri A. Developing an Intelligent System for Diagnosis of Asthma Based on Artificial Neural Network. Acta Inform Med. 2015; 23(4): 220-223.

27. Amaral J, Lopes AJ, Veiga J, Faria A, Melo PL. High-accuracy detection of airway obstruction in asthma using machine learning algorithms and forced oscillation measurements. Comput Methods Programs Biomed. 2017; 144: 113-125.

28. Amaral J, Sancho AG, Faria A, Lopes AJ, Melo PL. Differential diagnosis of asthma and restrictive respiratory diseases by combining forced oscillation measurements, machine learning and neuro-fuzzy classifiers. Med Biol Eng Comput. 2020; 58(10): 2455-2473.

29. Zhan J, Chen W, Cheng L, Wang Q, Han F, Cui Y. Diagnosis of Asthma Based on Routine Blood Biomarkers Using Machine Learning. Comput Intell Neurosci. 2020; 2020: 8841002.

30. Sinha A, Desiraju K, Aggarwal K, et al. Exhaled breath condensate metabolome clusters for endotype discovery in asthma. J Transl Med. 2017; 15(1): 262.

31. Pramono R, Bowyer S, Rodriguez-Villegas E. Automatic adventitious respiratory sound analysis: A systematic review. PLoS One. 2017; 12(5): e0177926.

32. Islam MA, Bandyopadhyaya I, Bhattacharyya P, Saha G. Multichannel lung sound analysis for asthma detection. Comput Methods Programs Biomed. 2018; 159: 111-123.

33. Bou Chebl R, Madden B, Belsky J, Harmouche E, Yessayan L. Diagnostic value of end tidal capnography in patients with hyperglycemia in the emergency department. BMC Emerg Med. 2016; $16: 7$.

34. Singh OP, Ramaswamy P, Malarvili M. Automatic Quantitative Analysis of Human Respired Carbon Dioxide Waveform for Asthma and Non-Asthma Classification Using Support Vector Machine. IEEE Access. 2018: 1-1.

35. Tomita K, Nagao R, Touge H, et al. Deep learning facilitates the diagnosis of adult asthma. Allergol Int. 2019; 68(4): 456-461.

36. Bacharier LB, Guilbert TW. Diagnosis and management of early asthma in preschool-aged children. J Allergy Clin Immunol. 2012; 130(2): 287-296.

37. Sittka A, Vera J, Lai X, Schmeck BT. Asthma phenotyping, therapy, and prevention: what can we learn from systems biology. Pediatr Res. 2013; 73(4 Pt 2): 543-552.

38. Howard R, Rattray M, Prosperi M, Custovic A. Distinguishing Asthma Phenotypes Using Machine Learning Approaches. Curr Allergy Asthma Rep. 2015; 15(7): 38

39. Korevaar DA, Westerhof GA, Wang J, et al. Diagnostic accuracy of minimally invasive markers for detection of airway eosinophilia in asthma: a systematic review and meta-analysis. Lancet Respir Med. 2015; 3(4): 290-300.

40. Couto M, Stang J, Horta L, et al. Two distinct phenotypes of asthma in elite athletes identified by latent class analysis. J Asthma. 2015; 52(9): 897-904.

41. Chen $\mathrm{Q}$, Just AC, Miller RL, et al. Using latent class growth analysis to identify childhood wheeze phenotypes in an urban birth cohort. Ann Allergy Asthma Immunol. 2012; 108(5): 311-315.

42. Weinmayr G, Keller F, Kleiner A, et al. Asthma phenotypes identified by latent class analysis in the ISAAC phase II Spain study. Clin Exp Allergy. 2013; 43(2): 223-232.

43. Bochenek G, Kuschill-Dziurda J, Szafraniec K, Plutecka H, Szczeklik A, Nizankowska-Mogilnicka E. Certain subphenotypes of aspirin-exacerbated respiratory disease distinguished by latent class analysis. J Allergy Clin Immunol. 2014; 133(1): 98-103.

44. Havstad S, Johnson CC, Kim H, et al. Atopic phenotypes identified with latent class analyses at age 2 years. J Allergy Clin Immunol. 2014; 134(3): 722-727.

45. Ross MK, Yoon J, van der Schaar A, van der Schaar M. Discovering Pediatric Asthma Phenotypes on the Basis of Response to Controller Medication Using Machine Learning. Ann Am Thorac Soc. 2018; 15(1): 49-58.

46. Wu W, Bang S, Bleecker ER, et al. Multiview Cluster Analysis Identifies Variable Corticosteroid Response Phenotypes in Severe Asthma. Am J Respir Crit Care Med. 2019; 199(11): 1358-1367.

47. Prosperi MC, Marinho S, Simpson A, Custovic A, Buchan IE. Predicting phenotypes of asthma and eczema with machine learning. BMC Med Genomics. 2014; 7(Suppl 1): S7.

48. Krautenbacher N, Flach N, Böck A, et al. A strategy for high-dimensional multivariable analysis classifies childhood asthma phenotypes from genetic, immunological, and environmental factors. Allergy. 2019; 74(7): 1364-1373.

49. Williams-DeVane CR, Reif DM, Hubal EC, et al. Decision tree-based method for integrating gene expression, demographic, and clinical data to determine disease endotypes. BMC Syst Biol. 2013; 7: 119 .

50. Siroux V, González JR, Bouzigon E, et al. Genetic heterogeneity of asthma phenotypes identified by a clustering approach. Eur Respir J. 2014; 43(2): 439-452.

51. Mäkikyrö EM, Jaakkola MS, Jaakkola JJ. Subtypes of asthma based on asthma control and severity: a latent class analysis. Respir Res. 2017; 18(1): 24.

52. Nabi FG, Sundaraj K, Lam CK, Palaniappan R. Characterization and classification of asthmatic wheeze sounds according to severity level using spectral integrated features. Comput Biol Med. 2019; 104: 52-61.

53. Moustris KP, Douros K, Nastos PT, et al. Seven-days-ahead forecasting of childhood asthma admissions using artificial neural networks in Athens, Greece. Int J Environ Health Res. 2012; 22(2): 93-104.
54. Messinger AI, Bui N, Wagner BD, Szefler SJ, Vu T, Deterding RR. Novel pediatric-automated respiratory score using physiologic data and machine learning in asthma. Pediatr Pulmonol. 2019; 54(8): 1149-1155.

55. Xiang Y, Ji H, Zhou Y, et al. Asthma Exacerbation Prediction and Risk Factor Analysis Based on a Time-Sensitive, Attentive Neural Network: Retrospective Cohort Study. J Med Internet Res. 2020; 22(7): e16981.

56. Khatri KL, Tamil LS. Early Detection of Peak Demand Days of Chronic Respiratory Diseases Emergency Department Visits Using Artificial Neural Networks. IEEE J Biomed Health Inform. 2018; 22(1): 285-290.

57. Grunwell JR, Gillespie S, Morris CR, Fitzpatrick AM. Latent Class Analysis of School-Age Children at Risk for Asthma Exacerbation. J Allergy Clin Immunol Pract. 2020; 8(7): 2275-2284.e2

58. Fitzpatrick AM, Bacharier LB, Jackson DJ, et al. Heterogeneity of Mild to Moderate Persistent Asthma in Children: Confirmation by Latent Class Analysis and Association with 1-Year Outcomes. J Allergy Clin Immunol Pract. 2020; 8(8): 2617-2627.

59. Das LT, Abramson EL, Stone AE, Kondrich JE, Kern LM, Grinspan ZM. Predicting frequent emergency department visits among children with asthma using EHR data. Pediatr Pulmonol. 2017; 52(7): 880-890.

60. Zhang O, Minku LL, Gonem S. Detecting asthma exacerbations using daily home monitoring and machine learning. J Asthma. 2020: 1-10.

61. Luo L, Liao C, Zhang F, et al. Applicability of internet search index for asthma admission forecast using machine learning. Int J Health Plann Manage. 2018; $1-10$.

62. Ram S, Zhang W, Williams M, Pengetnze Y. Predicting asthma-related emergency department visits using big data. IEEE J Biomed Health Inform. 2015; 19(4): 1216-1223.

63. Hosseini A, Buonocore CM, Hashemzadeh S, et al. Feasibility of a Secure Wireless Sensing Smartwatch Application for the Self-Management of Pediatric Asthma. Sensors (Basel). 2017; 17(8): 1780.

64. Finkelstein I, Jeong IC. Machine learning approaches to personalize early prediction of asthma exacerbations. Ann N Y Acad Sci. 2017; 1387(1): 153-165.

65. Huffaker MF, Carchia M, Harris BU, et al. Passive Nocturnal Physiologic Monitoring Enables Early Detection of Exacerbations in Children with Asthma. A Proof-of-Concept Study. Am J Respir Crit Care Med. 2018; 198(3): 320-328.

66. Luo L, Yu X, Yong Z, Li C, Gu Y. Design comorbidity portfolios to improve treatment cost prediction of asthma using machine learning. IEEE J Biomed Health Inform. 2020; PP.

67. Khasha R, Sepehri MM, Mahdaviani SA. An ensemble learning method for asthma control level detection with leveraging medical knowledge-based classifier and supervised learning. J Med Syst. 2019; 43(6): 158.

68. Tsang K, Pinnock H, Wilson AM, Ahmar Shah S. Application of Machine Learning to Support Self-Management of Asthma with mHealth. Annu Int Conf IEEE Eng Med Biol Soc. 2020; 2020: 5673-5677.

69. Hosseini SA, Jamshidnezhad A, Zilaee M, Fouladi Dehaghi B, Mohammadi A, Hosseini SM. Neural Network-Based Clinical Prediction System for Identifying the Clinical Effects of Saffron (Crocus sativus L) Supplement Therapy on Allergic Asthma: Model Evaluation Study. JMIR Med Inform. 2020; 8(7): e17580.

70. Mlodzinski E, Stone DJ, Celi LA. Machine Learning for Pulmonary and Critical Care Medicine: A Narrative Review. Pulm Ther. 2020; 6(1): 67-77.

71. Andreeva E, Pokhaznikova M, Lebedev A, Moiseeva I, Kuznetsova O, Degryse J. Spirometry is not enough to diagnose COPD in epidemiological studies: a follow-up study. NPJ Prim Care Respir Med. 2017; 27(5): 62.

72. Fulvio B, Pierachille S, Guido CA, et al. Chronic obstructive lung disease "expert system": validation of a predictive tool for assisting diagnosis. Int J Chron Obstruct Pulmon Dis. 2018; 13: 1747-1753.

73. Topalovic M, Das N, Burgel PR, et al. Artificial intelligence outperforms pulmonologists in the interpretation of pulmonary function tests. Eur Respir J. 2019; 53(4): 1801660

74. Matsumura K, Ito $S$. Novel biomarker genes which distinguish between smokers and chronic obstructive pulmonary disease patients with machine learning approach. BMC Pulm Med. 2020; 20(1): 29.

75. Zheng $\mathrm{H}, \mathrm{Hu} \mathrm{Y}$, Dong $\mathrm{L}$, et al. Predictive diagnosis of chronic obstructive pulmonary disease using serum metabolic biomarkers and least-squares support vector machine. J Clin Lab Anal. 2020: e23641.

76. Melbye H, Garcia-Marcos L, Brand P, Everard M, Priftis K, Pasterkamp H. Wheezes, crackles and rhonchi: simplifying description of lung sounds increases the agreement on their classification: a study of 12 physicians' classification of lung sounds from video recordings. BMJ Open Respir Res. 2016; 3(1): e000136.

77. Sarkar M, Madabhavi I, Niranjan N, Dogra M. Auscultation of the respiratory system. Ann Thorac Med. 2015; 10(3): 158-168.

78. Haider NS, Singh BK, Periyasamy R, Behera AK. Respiratory Sound Based Classification of Chronic Obstructive Pulmonary Disease: a Risk Stratification Approach in Machine Learning Paradigm. J Med Syst. 2019; 43(8): 255.

79. Spathis D, Vlamos P. Diagnosing asthma and chronic obstructive pulmonary disease with machine learning. Health Informatics J. 2019; 25(3): 811-827.

80. Gurbeta L, Badnjevic A, Maksimovic M, Omanovic-Miklicanin E, Sejdic E. A telehealth system for automated diagnosis of asthma and chronical obstructive pulmonary disease. J Am Med Inform Assoc. 2018; 25(9): 1213-1217.

81. Rodrigo GJ, Neffen H, Plaza V. Asthma-chronic obstructive pulmonary disease overlap syndrome: a controversial concept. Curr Opin Allergy Clin Immunol. 2017; 17(1): 36-41. 
82. Al Sallakh MA, Rodgers SE, Lyons RA, Sheikh A, Davies GA. Identifying patients with asthma-chronic obstructive pulmonary disease overlap syndrome using latent class analysis of electronic health record data: a study protocol. NPJ Prim Care Respir Med. 2018; 28(1): 22.

83. Nikolaou V, Massaro S, Fakhimi M, Stergioulas L, Price D. COPD phenotypes and machine learning cluster analysis: A systematic review and future research agenda. Respir Med. 2020; 171: 106093.

84. Pikoula M, Quint JK, Nissen F, Hemingway H, Smeeth L, Denaxas S. Identifying clinically important COPD sub-types using data-driven approaches in primary care population based electronic health records. BMC Med Inform Decis Mak. 2019; 19(1): 86.

85. Burgel PR, Paillasseur JL, Janssens W, et al. A simple algorithm for the identification of clinical COPD phenotypes. Eur Respir J. 2017; 50(5): 1701034

86. Yoon HY, Park SY, Lee $\mathrm{CH}$, et al. Prediction of first acute exacerbation using COPD subtypes identified by cluster analysis. Int J Chron Obstruct Pulmon Dis. 2019; 14: 1389-1397.

87. Kim WJ, Gupta V, Nishimura M, et al. Identification of chronic obstructive pulmonary disease subgroups in 13 Asian cities. Int J Tuberc Lung Dis. 2018; 22(7): 820-826

88. Castaldi PJ, Dy J, Ross J, et al. Cluster analysis in the COPDGene study identifies subtypes of smokers with distinct patterns of airway disease and emphysema. Thorax. 2014; 69(5): 415-422.

89. Castaldi PJ, Boueiz A, Yun J, et al. Machine Learning Characterization of COPD Subtypes: Insights From the COPDGene Study. Chest. 2020; 157(5): 1147-1157.

90. Bodduluri S, Nakhmani A, Reinhardt JM, et al. Deep neural network analyses of spirometry for structural phenotyping of chronic obstructive pulmonary disease. JCI Insight. 2020; 5(13): e132781.

91. Prieto-Centurion V, Rolle AJ, Au DH, et al. Multicenter study comparing case definitions used to identify patients with chronic obstructive pulmonary disease. Am J Respir Crit Care Med. 2014; 190(9): 989-995.

92. Wu H, Wise RA, Medinger AE. Do Patients Hospitalized With COPD Have Airflow Obstruction. Chest. 2017; 151(6): 1263-1271.

93. Akgün KM, Sigel K, Cheung KH, et al. Extracting lung function measurements to enhance phenotyping of chronic obstructive pulmonary disease (COPD) in an electronic health record using automated tools. PLoS One. 2020; 15(1): e0227730.

94. Gawlitza J, Sturm T, Spohrer K, et al. Predicting Pulmonary Function Testing from Quantified Computed Tomography Using Machine Learning Algorithms in Patients with COPD. Diagnostics (Basel). 2019; 9(1): 33.

95. Westcott A, Capaldi D, McCormack DG, Ward AD, Fenster A, Parraga G. Chronic Obstructive Pulmonary Disease: Thoracic CT Texture Analysis and Machine Learning to Predict Pulmonary Ventilation. Radiology. 2019; 293(3): 676-684.

96. González G, Ash SY, Vegas-Sánchez-Ferrero G, et al. Disease Staging and Prognosis in Smokers Using Deep Learning in Chest Computed Tomography. Am J Respir Crit Care Med. 2018; 197(2): 193-203.

97. Peng J, Chen C, Zhou M, Xie X, Zhou Y, Luo CH. A Machine-learning Approach to Forecast Aggravation Risk in Patients with Acute Exacerbation of Chronic Obstructive Pulmonary Disease with Clinical Indicators. Sci Rep. 2020; 10(1): 3118

98. Goto $\mathrm{T}$, Jo $\mathrm{T}$, Matsui $\mathrm{H}$, Fushimi $\mathrm{K}$, Hayashi $\mathrm{H}$, Yasunaga $\mathrm{H}$. Machine Learning-Based Prediction Models for 30-Day Readmission after Hospitalization for Chronic Obstructive Pulmonary Disease. COPD. 2019; 16(5-6): 338-343.

99. Min X, Yu B, Wang F. Predictive Modeling of the Hospital Readmission Risk from Patients' Claims Data Using Machine Learning: A Case Study on COPD. Sci Rep. 2019; 9(1): 2362.

100. Cavailles A, Melloni B, Motola S, et al. Identification of Patient Profiles with High Risk of Hospital Re-Admissions for Acute COPD Exacerbations (AECOPD) in France Using a Machine Learning Model. Int J Chron Obstruct Pulmon Dis. 2020: 15: 949-962.

101. Chen W, Sin DD, FitzGerald JM, Safari A, Adibi A, Sadatsafavi M. An Individualized Prediction Model for Long-term Lung Function Trajectory and Risk of COPD in the General Population. Chest. 2020; 157(3): 547-557.

102. Ma X, Wu Y, Zhang $\mathrm{L}$, et al. Comparison and development of machine learning tools for the prediction of chronic obstructive pulmonary disease in the Chinese population. J Transl Med. 2020; 18(1): 146.

103. Lanclus M, Clukers I, Van Holsbeke C, et al. Machine Learning Algorithms Utilizing Functional Respiratory Imaging May Predict COPD Exacerbations. Acad Radiol. 2019; 26(9): 1191-1199.

104. Wang $C$, Chen $X$, Du L, Zhan $Q$ Yang $T$, Fang $Z$ Comparison of machine learning algorithms for the identification of acute exacerbations in chronic obstructive pulmonary disease. Comput Methods Programs Biomed. 2020; 188: 105267

105. Hardinge $\mathrm{M}$, Rutter $\mathrm{H}$, Velardo $\mathrm{C}$, et al. Using a mobile health application to support self-management in chronic obstructive pulmonary disease: a six-month cohort study. BMC Med Inform Decis Mak. 2015; 15: 46.

106. Bonten MJ, Huijts SM, Bolkenbaas M, et al. Polysaccharide conjugate vaccine against pneumococcal pneumonia in adults. N Engl J Med. 2015; 372(12): $1114-1125$

107. Luo L, Li J, Lian S, et al. Using machine learning approaches to predict high-cost chronic obstructive pulmonary disease patients in China. Health Informatics J. 2020; 26(3): 1577-1598.
108. Morales DR, Flynn R, Zhang J, Trucco E, Quint JK, Zutis K. External validation of ADO, DOSE, COTE and CODEX at predicting death in primary care patients with COPD using standard and machine learning approaches. Respir Med. 2018; 138: 150-155.

109. Moll M, Qiao D, Regan EA, et al. Machine Learning and Prediction of All-Cause Mortality in COPD. Chest. 2020; 158(3): 952-964.

110. Orchard P, Agakova A, Pinnock H, et al. Improving Prediction of Risk of Hospital Admission in Chronic Obstructive Pulmonary Disease: Application of Machine Learning to Telemonitoring Data. J Med Internet Res. 2018; 20(9): e263.

111. Franssen FM, Alter P, Bar N, et al. Personalized medicine for patients with COPD: where are we. Int J Chron Obstruct Pulmon Dis. 2019; 14: 1465-1484.

112. Agusti A, Calverley PM, Celli B, et al. Characterisation of COPD heterogeneity in the ECLIPSE cohort. Respir Res. 2010; 11(1): 122. 